\title{
1 Current best practice for disease activity assessment in IBD
}

3 Alissa J. Walsh ${ }^{1^{*}}$, Robert V. Bryant ${ }^{2,3^{*}}$ and Simon P. L. Travis ${ }^{1}$

$5{ }^{1}$ Translational Gastroenterology Unit, Experimental Medicine Division, John Radcliffe

6 Hospital, Headley Way, Headington, Oxford, OX3 9DU, United Kingdom

72 . Department of Gastroenterology and Hepatology, Royal Adelaide Hospital, North

8 Terrace, Adelaide, South Australia, 5000, Australia

${ }^{3}$ School of Medicine, University of Adelaide, Adelaide, South Australia, 5005,

10 Australia.

11 *These authors are joint first authors.

12 Correspondence to A.J.W

alissa.walsh@linacre.ox.ac.uk

\section{Key points:}

- Objective assessment of disease activity assessment in IBD is important for guiding subsequent therapy as a part of a 'treat to target' strategy

- Multiple domains of disease activity assessment exist in IBD (symptoms, endoscopy, histology, radiology, biomarkers and quality of life), and targets should be recognized as goals for therapy within each domain

- Confusing terminology and the use of composite indices (combining symptom assessment with objective measurements of quality of life or inflammation) confound the formal evaluation of disease activity

- Biomarkers are useful adjuncts to monitor disease activity in both ulcerative colitis and Crohn's disease

- Assessment of quality of life is an important aspect of medical decision-making, as improving quality of life is a major goal of therapy 


\section{Abstract}

7 Therapeutic advances in the management of IBD have led to a paradigm shift in the

8 assessment of IBD disease activity. Beyond clinical remission, objective assessment

9 of inflammation is now critical to guiding subsequent therapy as part of a treat to

10 target' strategy. Multiple domains of disease activity assessment in IBD exist, each

11 of which has its merits, although none are perfect. The aim of this Review is to

12 comprehensively evaluate measures of disease activity in both ulcerative colitis and

13 Crohn's disease, including clinical, endoscopic, histological and radiological

14 assessment tools, as well as the use of biomarkers and quality of life (QOL)

15 evaluation. A subjective appraisal of the best indices for use in clinical practice is

16 provided, based on index validation, responsiveness and experience in clinical trials,

17 international specialist opinion, and practicality and suitability for use in clinical

18 practice. The aim of this Review is to enable the reader to gain confidence in IBD

19 disease activity assessment and to give ready access to the necessary tools. 
1 Management of IBD is guided by the anatomical distribution of disease, symptom

2 severity, response to medical therapy and the ability of the patient to accept and

3 tolerate treatment. ${ }^{1,2}$ Disease severity indices help to guide clinical decisions and are

4 particularly helpful for patients who fail to show adequate response to therapy as

5 they clearly show (in a quantitative manner) that they have not met the desired

6 target. (Table 1, 2). Advances such as increased availability and use of biologic

7 agents for the treatment of IBD have led to a paradigm shift in the assessment of

8 disease activity as we are now better able to achieve remission targets. Beyond

9 clinical remission, ongoing treatment strategies require guidance from objective

10 assessment of disease activity. IBD disease activity comprises multiple domains that

11 can be assessed; each of these domains has its merits, although none are perfect

12 (FIG 1.).

13

14 The aim of this Review is to evaluate measures of disease activity assessment in

15 both ulcerative colitis and Crohn's disease. Formal evaluation of disease activity in

16 IBD is associated with many challenges, including confusing terminology, different

17 names or abbreviations for the same index, and the tendency to use composite

18 indices that combine symptom assessment with objective measures of inflammation

19 or quality of life (QOL).

21 To make this summary clinically useful, we have divided the paper into sections on ulcerative colitis and Crohn's disease;in each we will discuss clinical, endoscopic, histological and radiological assessment, as well as biomarkers and QOL. A subjective evaluation of the best disease activity indices for use in clinical practice is provided. Remission thresholds for disease activity indices are also provided when 
1 possible. The indices were selected after several considerations: extent of validation;

2 responsiveness and experience in clinical trials; international expert opinion; ${ }^{3}$ active

3 comparison between all indices in clinical practice; ${ }^{4}$ and ease of use in clinical

4 practice. Although to some extent the choice of indices was that of the authors, the

5 selection is informed by our extensive involvement in index development, evaluation,

6 formal guideline development, clinical trials and clinical practice. ${ }^{3-9}$ This Review

7 aims to give the reader ready access to appropriate assessment tools, and enable

8 the reader to gain confidence in IBD disease activity assessment. A comprehensive

9 list of relevant disease activity indices is provided as a supplementary table for both

10 ulcerative colitis and Crohn's disease (see Supplementary information S1 (tables 1

11 and 2, respectively) online).

12 A good case can be made (and one that we advocate) for separating the components of disease activity assessment, using distinct and independently

14 validated clinical, endoscopic, histological and QOL indices. We recognize that this

15 might as yet represent a minority view, but we believe it will gain ground, particularly

16 as QOL becomes an important outcome measure for care. 
2 [H1] Ulcerative colitis

3 [H3]Clinical assessment of disease activity.

5 There are 17 ulcerative colitis indices that evaluate symptoms, eight of which do so

6 independently of endoscopic scoring or biochemical markers (see Supplementary

7 information S1 (table 1) online). For assessment of mild to moderate ulcerative colitis

8 we recommend the Simple Colitis Clinical Activity index (SCCAI), ${ }^{10}$ Partial Mayo

9 Clinic Index ${ }^{11,12}$ and the Pediatric Ulcerative Colitis Activity Index (PUCAI). ${ }^{13}$ For severe disease, we recommend Truelove and Witts' criteria. ${ }^{14}$

12 The SCCAI (see Supplementary information S2 (table 1) online) is one of the eight

13 indices that excludes endoscopic assessment and biochemical markers., Importantly, it includes nocturnal bowel movements and urgency of defecation. ${ }^{10}$ These symptoms are of vital importance to patients due to their effect on QOL, but are neglected by other indices. Scores in this index range from 0 to 19 points. The SCCAI has been compared prospectively with the multiple other ulcerative colitis indices and, along with the PUCAI, performed best of all noninvasive indices for validity, reliability, responsiveness (ability to measure the change in disease activity) and feasibility. This index was sufficiently able to discriminate remission from active disease. ${ }^{15}$ As the SCCAI does not include a Physician's Global Assessment or biochemical markers, it can readily be completed by patients. The remission target is a SCCAI total score of $<1 .^{3}$ currently the most widely used index in trial design. ${ }^{11,12}$ The full Mayo Clinic Index 
1 (Partial Mayo Clinic Index plus endoscopic subscore) has become the standard for

2 assessing disease activity in adult clinical trials in which endoscopic assessment is

3 mandated by the FDA. ${ }^{16}$ Rectal bleeding and frequency of bowel motions are the

4 only two symptoms assessed. Although readily criticized because it is an unvalidated

5 derivation of an unvalidated index, when the Partial Mayo Index was compared with

6 other noninvasive indices, this index performed well for discriminating remission from

7 active disease, showed responsiveness and good construct validity. Insufficient test-

8 retest validity were shown. ${ }^{15}$ A Global Physician assessment is necessary for the

9 Partial Mayo Index and therefore makes it less feasible for clinical use [Au:OK?] .

10 The remission target is a Partial Mayo total score of $\leq 1$. $^{3}$

12 The PUCAI (see Supplementary information S2 (table 3) online) was devised by

13 paediatric gastroenterologists as a noninvasive instrument to assess disease activity

14 in children; repeated endoscopy in this setting is less tolerable to both patients and

15 parents. ${ }^{13}$ This index comprises six descriptors, each with different levels, creating a

16 total score ranging from 0 to 85: abdominal pain, degree of rectal bleeding, average

17 stool consistency, number of stools in $24 \mathrm{~h}$, presence of nocturnal stools and patient

18 activity level are assessed. The PUCAI was rigorously developed and validated in

19 children, ${ }^{13}$ and has also been shown to be valid, reliable and responsive in adults. ${ }^{15}$

20 This index permits less frequent endoscopic assessment for all patients with

21 ulcerative colitis, both in clinical practice and clinical trials. ${ }^{15}$ The remission target is

22 a PUCAI total score of $<10 .^{3}$

24 For severe disease assessment and management we encourage the use of the

25 Truelove and Witts' criteria (see Supplementary information S2 (table 4) online). ${ }^{14}$ 
1 This index provides objective criteria to identify acute severe colitis, and has been

2 widely used to define the need for hospital admission and intravenous steroids. ${ }^{17}$

3 The criteria for acute severe colitis are $\geq 6$ stools per day, with frequent blood in the

4 stool, with at least one of the following features: body temperature $>37.8^{\circ} \mathrm{C}$; heart

5 rate $>90 \mathrm{bpm}$, haemoglobin levels $<10.5 \mathrm{~g} / \mathrm{dL}$ [Au:OK?] and erythrocyte

6 sedimentation rate $>30 \mathrm{~mm} / \mathrm{h}$. Patients with more of these criteria present at

7 admission have a greater chance of needing a colectomy on that admission. ${ }^{18}$

8

9

10

11

12

13

14

15

Many different endoscopic indices for ulcerative colitis have been used in clinical

[H3]Endoscopic assessment of disease activity.

Mucosal healing is the remission target when assessing IBD disease activity endoscopically. . Simply stated, mucosal healing should imply the absence of ulceration and erosions. Nevertheless, there is currently no validated definition of mucosal healing in IBD. ${ }^{16,19,20}$

Mucosal healing should be recognized as the ultimate therapeutic goal for ulcerative colitis, as the disease is limited to the mucosa. ${ }^{19}$ Thus, endoscopic assessment of patients with ulcerative colitis is increasingly used in clinical practice to guide treatment decision-making. Mucosal healing in ulcerative colitis has been associated with decreased need for corticosteroids, ${ }^{21}$ decreased hospitalization rates, ${ }^{22-24}$ sustained clinical remission, ${ }^{25}$ decreased colectomy ${ }^{21,22,24,25}$ and decreased risk of colorectal cancer. ${ }^{26}$ trials (see Supplementary information S1 (table 1) online). This Review focuses on 
1 the endoscopic indices that we, the authors, feel are best used in clinical practice:

2 the Ulcerative Colitis Endoscopic Index of Severity (UCEIS) ${ }^{8,9}$ and Mayo Clinic

3 endoscopy subscore. ${ }^{11}$

4 The UCEIS is the only validated endoscopic index in ulcerative colitis (see 5 Supplementary information S2 (table 5) online), ${ }^{8,9}$ and was developed because of 6 wide inter-observer variation in endoscopic assessment of disease activity when 7 using previously published endoscopic indices. ${ }^{4}$ The UCEIS is simple to use in 8 clinical practice, as all it requires is the endoscopist to grade vascular pattern, 9 bleeding and erosions or ulceration, which then allows a total score from 0 to 8 to be calculated. Disadvantages of the UCEIS are that extent of disease is not 11 documented (as only the worst affected area is scored), there is no definition of 12 mucosal healing, nor are there any validated thresholds for mild, moderate or severe disease. Use of the UCEIS has been shown to reduce inter-observer variation, 8,27 and its responsiveness will be defined by its use in clinical trials of ulcerative colitis that are currently in progress. ${ }^{28}$ We encourage its use in clinical practice so that there is a uniform language for describing disease activity. The remission target is a

17 UCEIS total score of $\leq 1 .^{3}$

The Mayo Clinic endoscopy subscore has not been formally validated, however it has been the standard for assessing disease activity in adult clinical trials where endoscopic assessment is mandated by the FDA. ${ }^{16}$ The subscore has four components, each with a maximum score of 3 (see Supplementary information S2 (table 6) online). ${ }^{2}$ Overlap in the features of the different levels contributes to interobserver variation; moreover, the index [Au:OK?] does not take into account extent 
1 of disease and there is no validated definition of mucosal healing. The value of using

2 the Mayo Clinic Score in clinical practice simply reflects familiarity among

3 practitioners. The remission target is a Mayo Clinic endoscopy subscore of $\leq 1$,

4 reflecting the use of this threshold as an outcome measure in clinical trials, its

5 association with a lower colectomy rate during follow-up, and recommendation by a

6 group of international specialists. ${ }^{3}$

7

8 [H3] Histological assessment of disease activity.

9 Substantial disparity exists between histological and endoscopic disease activity 10 assessment in ulcerative colitis. ${ }^{5}$ Microscopic inflammation can persist despite the appearance of endoscopically healed colonic mucosa, representing a harbinger of

12 residual active disease. ${ }^{29,30}$ Accordingly, observational studies have shown that

13 persistent histological inflammation in ulcerative colitis is associated with an

14 increased risk of clinical relapse, hospitalization, colectomy and colorectal

15 neoplasia. ${ }^{30-33}$ Histological remission is not yet recommended as a target of

16 treatment in either clinical trials or practice ${ }^{3}$, however the FDA are considering

17 documentation of patient histological disease activity at trial inclusion and as an outcome measure in clinical trials. ${ }^{5}$ Histological healing represents 'complete' remission in ulcerative colitis, and given its association with improved patient outcomes and reduced disease-related complications, is likely to be a future therapeutic target in clinical practice. ${ }^{5}$

23 There are 26 histological activity indices in ulcerative colitis, only two of which are

24 validated (see Supplementary information S1 (table 1) online). ${ }^{6,34}$ As a consequence, no gold standard exists for assessing histological disease activity, nor for defining 
1 histological remission, in patients with ulcerative colitis. The operating characteristics

2 of any histological scoring system in ulcerative colitis depend on the number, quality

3 and distribution of colonic biopsy samples taken, as well as the histological features

4 incorporated. $5,35,36$ Histological features with the highest intra-observer and inter-

5 observer agreement are erosion or ulceration, and the presence and density of

6 lamina propria neutrophil infiltrates. ${ }^{36,37}$ Basal plasmacytosis has been associated

7 with increased risk of ulcerative colitis relapse, ${ }^{30}$ but concordance between reporting

8 histopathologists is poor. ${ }^{36,37}$

Until 2015, the Riley Score (see Supplementary information S2 (table 7) online), ${ }^{38}$ and the Geboes Score (see Supplementary information S2 (table 8) online) were the most useful histological indices in patients with ulcerative colitis. ${ }^{39}$ These scoring systems are widely used, and each has been shown to predict clinical relapse in 14 patients with endoscopically quiescent disease. ${ }^{30,38,40}$ However, the operating characteristics of the scores in assessing the intended histological parameters are only partially validated and each includes histological features, such as crypt destruction, crypt architectural changes, and lamina propria eosinophils that lack reproducibility. ${ }^{36,37}$ Two new, validated indices have been developed for use in patients with ulcerative colitis: the Nancy Index (see Supplementary information S2 (table 9) online), ${ }^{6}$ and the Robarts Histopathology Index (RHI; see Supplementary information S2 (table 10) online). ${ }^{34}$ Of these indices, the Nancy Index is our recommendation for use in clinical practice, because of its simplicity, reproducibility and ease of use, whereas the $\mathrm{RHI}$ will probably be preferred for clinical trials, owing to well-defined responsiveness. 
1 The Nancy Index and the $\mathrm{RHI}$ are validated, reproducible and responsive. ${ }^{6,34}$ The

2 Nancy Index has three histological descriptors (the presence of ulceration, the

3 severity of acute inflammatory infiltrate and the severity of chronic inflammatory

4 infiltrate) defining five grades of activity (grade 0 , least severe disease, to grade 4 ,

5 most severe disease) in a weighted scoring algorithm (presence of ulceration defines

6 the most severe disease). ${ }^{6}$ The $\mathrm{RHI}$ incorporates four histological descriptors

7 (severity of chronic inflammatory infiltrate, the number of lamina propria neutrophils,

8 the number of neutrophils in the epithelium and the severity of erosions or

9 ulceration), each of which is objectively graded between 0 and 3. Using data from a

10 phase II trial of vedolizumab, this index has been shown to be responsive to disease

11 activity change, and is probably a useful tool for clinical trials. ${ }^{41}$

[H3]Radiological assessment of disease activity.

14 Imaging techniques are adjunctive to endoscopic assessment of disease activity in

15 ulcerative colitis, and resolution of radiologic abnormalities in UC is not considered a

16 treatment target in clinical practice..$^{3,42}$

Abdominal radiography is indicated in patients with severe ulcerative colitis to assess the extent of faecal residue, colonic dilatation or mucosal islands (areas of preserved colonic mucosa amidst denuded ulcerated mucosa). ${ }^{42}$ Features on plain abdominal radiography, in particular toxic megacolon (colonic dilatation $>5.5 \mathrm{~cm}$ ), assist with prognostication of patients with severe colitis, and can guide management toward colectomy. ${ }^{42,43}$ Plain abdominal radiography has no role in ulcerative colitis disease activity assessment outside of the acute setting, as it lacks sensitivity in evaluating 
1 mild-moderate grades of disease severity, but might identify proximal constipation

2 as a cause of refractory distal disease. ${ }^{42,44}$

4 Cross-sectional imaging in ulcerative colitis is predominantly performed to assess

5 complications of disease, to exclude small bowel inflammation and Crohn's disease

6 as a differential diagnosis and to assess colonic disease when stenosis or severe

7 comorbidities limit the utility of colonoscopy. ${ }^{17,42} \mathrm{CT}$ is associated with radiation

8 exposure and has little role in assessing disease activity in ulcerative colitis;

9 inflammation as assessed by CT correlates only moderately with endoscopic colonic 10 inflammation (sensitivity $74 \%),{ }^{45}$ and use of CT infrequently leads to a change in 11 clinical management. ${ }^{46}$

13 MRI and bowel ultrasonography demonstrate good sensitivity for evaluating disease 14 activity and extent in ulcerative colitis without associated ionizing radiation, and represent the most useful techniques for assessing luminal disease activity in ulcerative colitis when patient or disease-related factors render endoscopic examination infeasible. ${ }^{42}$ (see Supplementary information S1 (table 1) online). Two scoring systems have been described for the assessment of colonic inflammation in ulcerative colitis with MRI, one with and one without bowel preparation. ${ }^{47,48} \mathrm{~A}$

20 simplified magnetic resonance colonography index (MRC-S), based on four

21 radiological features (gadolinium contrast uptake, presence of oedema,

22 lymphadenopathy, and presence of the comb sign (hypervascularity of the mesentery)), correlates significantly with endoscopy as a reference standard

$24(r=0.81, P<0.001)$ (see Supplementary information S2 (table 11) online). ${ }^{47}$ The 
1 active disease (87\% and $88 \%$ respectively). Using MRI and diffusion-weighted

2 imaging (technique used to evaluate cellular movement within a tissue voxel) without

3 bowel preparation, a segmental MRI score (MR-score-S) of $>1$, demonstrated a

4 sensitivity and specificity of $89 \%$ and $86 \%$ for active disease (see Supplementary

5 information S2 (table 12) online). ${ }^{48}$ The MR-score-S is calculated from six

6 radiological features, including the presence of intestinal ulceration, parietal oedema,

7 and differentiation between bowel wall layers.. The MRC-S might be a simpler score

8 to use in clinical practice as it includes fewer variables, however the MR-score-S is

9 benefited by not requiring bowel preparation

11 Disease assessment by bowel ultrasonography has been shown to correlate with colonic inflammation in ulcerative colitis, although performance is operatordependent and might not be generalizable. ${ }^{42}$ An ultrasonography scoring system proposed by Parente et al. ${ }^{49}$ is useful in clinical practice and incorporates measurement of colonic wall thickness with the degree of intramural blood flow (Supplementary information S2 (table 13) online). ${ }^{49,50}$ This score is concordant with the severity of endoscopically assessed inflammation in moderate to severe ulcerative colitis (weighted kappa 0.76-0.90), and is responsive to disease activity change after steroid therapy, predicting disease outcomes at 15 months. ${ }^{49}$ Bowel ultrasonography is a helpful adjunct to endoscopy in ulcerative colitis, as it is a cheap, noninvasive, and non-irradiating means of monitoring disease activity and extent, and is convenient to patients given that it can [Au:OK?] be readily performed in the clinical setting. ${ }^{51}$ However, expertise in bowel ultrasonography might be

24 limited in many centres, and MRI might be the preferred imaging modality. 


\section{1 [H3]Biomarkers to assess disease activity.}

2 Biomarkers are a useful adjunct to endoscopy for assessing disease activity in

3 ulcerative colitis, ${ }^{3}$ in that they are non-invasive and yet provide objective evidence of

4 inflammation beyond clinical assessment alone. The most useful biomarkers in

5 ulcerative colitis are plasma levels of C-reactive protein (CRP) and faecal 6 calprotectin.

7

$8 \mathrm{CRP}$ is a useful marker in clinical practice for predicting disease outcomes at the 9 time of diagnosis of ulcerative colitis, and in patients with severe ulcerative colitis. 10 Plasma CRP levels have been shown to predict the risk of colectomy in patients with 11 ulcerative colitis. ${ }^{52-57}$ The Oxford criteria (more than eight stools per day or $3-8$ stools per day and plasma CRP concentration $>45 \mathrm{mg} / \mathrm{l}(>428.6 \mathrm{nmol} / \mathrm{l}))$ predicts an $85 \%$ risk of colectomy during the period of that hospital admission after 3 days of

14 intravenous corticosteroid therapy for acute severe colitis (Supplementary information S2 (table 14) online). ${ }^{55}$ These criteria provide an indication of the need 16 for medical rescue therapy, such as cyclosporine or infliximab. ${ }^{1}$ A scoring system 17 involving plasma CRP levels, extent of disease, and serum hemoglobin levels at the time of diagnosis of UC, has been shown to predict the risk of acute severe colitis within 3 years. ${ }^{58,59}$ Although a reduction in plasma CRP level has been shown to correlate with treatment response, CRP concentration is less useful in quiescent, mild, or moderately active ulcerative colitis, as it correlates weakly with endoscopic disease activity ${ }^{60}$

24 Faecal calprotectin level is a useful noninvasive tool for monitoring disease activity 25 over time. This biomarker has been shown to predict persistent inflammation ${ }^{61-63}$ and 
1 risk of relapse ${ }^{64-68}$ in patients with ulcerative colitis, and is responsive to up-titration

2 of therapy. ${ }^{69}$ However, a single faecal calprotectin cut-off value to predict

3 endoscopically assessed disease remission is not credible, because a broad range

4 of cut-off values have been described (ranging from $<50 \mu \mathrm{g} / \mathrm{g}$ to $<250 \mu \mathrm{g} / \mathrm{g}$ ), mostly

5 with only moderate sensitivity and specificity for disease activity. ${ }^{70,71}$ Faecal

6 calprotectin level varies widely between stools on a daily basis in patients with active

7 ulcerative colitis, ${ }^{72}$ and readings can be influenced by variability inherent in the

8 assay. ${ }^{73}$ The clinical utility of faecal calprotectin levels for an individual patient lies in

9 monitoring the change of this biomarker over time ( $\Delta$ faecal calprotectin); rising faecal

10 calprotectin levels prompt endoscopic evaluation and guide therapy. No useful disease activity scoring system based upon faecal calprotectin levels exists.

13 [H3] QOL in ulcerative colitis.

14 Measurement of QOL is important in the assessment of IBD because it evaluates the 15 patient's social and emotional well-being, behaviour and attitudes, and (to some extent) physical disease-related symptoms. QOL assessments are now an important component of medical decision-making, as improving QOL is the ultimate goal of therapy and value-based health care [Au:Sentence OK?] An international working group is developing a standard set of measures in IBD (www.ichom.org), and are due to report in late 2016.. Nevertheless, most disease-specific QOL indices (such as the IBDQ ${ }^{74}$ ) for IBD are lengthy and time-consuming and this often precludes their use in clinical settings.. The challenge is to find a measure of QOL that is fast to complete, valid, internally reliable, reproducible, responsive and acceptable to 24 patients. 
1 The questionnaire that we recommend for use in clinical practice is the IBD-

2 Control.(Supplementary information S2 (table 15) online). ${ }^{75}$ IBD-Control is the first

3 patient-related outcome measure to capture disease control from the patient's

4 perspective, using a simple set of generic terms applicable to both ulcerative colitis

5 and Crohn's disease. Summary scores show strong validity versus more complex

6 QOL questionnaires, disease activity scores and Global Physician Assessment. ${ }^{75} \mathrm{~A}$

7 limited version, IBD-Control 8, includes the questionnaire elements $1 \mathrm{a}, 1 \mathrm{~b}$ and $3 \mathrm{a}-3 \mathrm{f}$,

8 with the total score being calculated as follows: the 'worst' response is scored 0

9 (being either a 'Yes' or 'No' depending on the question), 'not sure' is scored 1, and

10 the 'best' response (being either a 'Yes' or 'No' depending on the question) is scored

11 2. For IBD-Control-8, if all response are favourable, the maximum score is 16 ,

12 equating to the best disease control [Au:Edit of this section OK?] . This questionnaire is free to use and (unlike the Short Inflammatory Bowel Disease Questionnaire (SIBDQ)) not subject to license. Its simplicity, the fact that it is completed by patients, and that it has been adopted by international groups (ICHOM and the UK IBD Registry) are other advantages.

Other QOL questionnaires used in clinical practice include the SIBDQ ${ }^{76}$ (see

Supplementary information S2 (table 16)) and the Crohn's Ulcerative Colitis

Questionnaire-8 (CUCQ-8) ${ }^{77}$ (see Supplementary information S2 (table 17)). These short questionnaires (the SIBDQ has 10 questions and the CUCQ-8 has eight questions) explain $>95 \%$ of the variance of their respective 32 question versions (the IBDQ and the CUCQ-32) 
1 The SIBDQ gives results similar to the full 32-item IBDQ, ${ }^{74}$ is widely accepted and

2 has been validated in different populations. ${ }^{76}$ Scores generated by this index range

3 from 10-70, which correspond to poor-to-good QOL, respectively. This questionnaire

4 is reproducible and responsive to changes in disease severity ${ }^{78}$, but there is a

5 licensing fee attached to its use.

6

7 The CUCQ-8, developed from the CUCQ-32, was designed for use in clinical

8 practice, both for patients with stable disease as well as those with acute IBD.

9 Scores range from 0-8, which correspond to good to poor QOL, notably the opposite

10 way around to the SIBDQ and IBD-Control. The CUCQ-8 requires no licensing fee

11 for its use and is the only QOL index that has been used as a primary end-point in a

12 randomized clinical trial (CONSTRUCT) in ulcerative colitis. ${ }^{79}$

13 


\section{[H1] Crohn's disease}

\section{[H3]Clinical assessment of disease activity.}

The Crohn's Disease Activity Index (CDAI, see Supplementary information S2 (table

18)) is the most commonly used tool for assessing disease response to treatment in

Crohn's disease clinical trials. ${ }^{80}$ However, calculation of the CDAl is complex and involves eight items, including haematocrit, physical examination (abdominal examination and weight measurement) and a 7-day patient diary (to record number of soft tools, abdominal pain and general well-being), so it is rarely used in clinical practice. Inter-observer variability between CDAI scores is high, even among experienced physicians. ${ }^{81}$ The remission target is a CDAI $<150 .{ }^{3}$

The Harvey-Bradshaw Index ( $\mathrm{HBI})^{82}$ (see Supplementary information S2 (table 19) online) is simpler to use than the CDAI and this makes data collection easier ${ }^{83}$; moreover, scores from this index have been shown to correlate closely with CDAI scores. ${ }^{83}$ The $\mathrm{HBI}$ has five variables (including general well-being, severity of abdominal pain, number of liquid stools, presence of abdominal mass and presence of complications) and items are scored based upon the previous day, so it does not require prospective 7-day data collection. The remission target for this index is an $\mathrm{HBI}$ score $\leq 4 .^{3}$

The CDAl is not an accurate instrument to assess the activity of perianal Crohn's disease or Crohn's disease with other fistulae, because the presence of perianal disease or other fistulae (which can be terribly disabling for the patient) only accounts for a small proportion of the total score.. The perianal Crohn's disease activity index (PDAI) ${ }^{84}$ is currently the gold standard for evaluating the severity of 
1 perianal disease (see Supplementary information S2 (table 20) online). This index

2 comprises five items: discharge; pain; restriction of sexual activity; type of perianal

3 disease; degree of induration. Discharge, pain and degree of induration seem to be

4 more commonly used in clinical practice.

5

6 [H3]Endoscopic assessment of disease activity.

7 In contrast to ulcerative colitis, mucosal healing in Crohn's disease might reasonably

8 be considered a minimal (rather than the ultimate) therapeutic goal, because Crohn's

9 disease is transmural. The benefits of achieving mucosal healing include decreased

10 need for corticosteroids, decreased hospitalization, sustained clinical remission and

11 decreased need for surgery. ${ }^{21,23,24}$

12 Complete resolution of all endoscopically visible ulcers is a simple definition of mucosal healing for clinical practice and has been recommended by international consensus bodies. ${ }^{85}$ Nevertheless, the binomial definition (presence or absence of ulcers) is currently unvalidated, difficult to achieve and crude, because it does not allow quantification of improvement of mucosal inflammation. ${ }^{86}$

17 Validated endoscopic indices have been developed for the assessment of Crohn's 18 disease activity (see Supplementary information S1 (table 2) online). The Crohn's

19 Disease Activity Index of Severity (CDEIS) ${ }^{87}$ is the most commonly used tool in 20 clinical trials, whereas the Simple Endoscopic Score for Crohn's Disease (SES$21 \mathrm{CD})^{88}$ is a slightly simplified version of the same index. Rutgeerts' Post-operative 22 Endoscopic Index ${ }^{89}$ is used for estimating the risk of disease recurrence after 23 ileocolic resection for Crohn's disease. 
1 The CDEIS examines four endoscopic variables (the presence of deep ulceration,

2 superficial ulceration, the length of ulcerated mucosa and the length of diseased

3 mucosa) in each of the following locations: rectum, sigmoid and left colon, transverse

4 colon, right colon and ileum (see Supplementary information S2 (table 21) and

5 Supplementary information S3 (file) online). Although the CDEIS is a reproducible

6 and validated index, it is complex, requiring over 30 entries to reach the final score. ${ }^{87}$

7 As with all indices, implementation requires both training and experience, but the

8 complexity of the CDEIS makes it cumbersome to use in clinical practice. The

9 remission target is a total CDEIS score of $<3 .^{3}$

11 The SES-CD (see Supplementary information S2 (table 22) online) correlates well with the CDEIS, but is only slightly less complex, requiring over 20 entries to complete the total score, and therefore also being difficult to complete in routine clinical practice.. ${ }^{88}$ Endoscopic features (ulcer size, extent of ulcerated surfaces, extent of surfaces with any other lesions and stenosis) are scored from 0 to 3 depending on severity or extent in each of the five colorectal locations assessed by the CDEIS. An SES-CD score of 0 equates to absence of ulcers.

Rutgeerts' Post-operative Endoscopic Index (see Supplementary information S2 (table 23) online) determines the severity of endoscopic disease recurrence at the anastomosis and in the neo-terminal ileum after ileocolic resection. ${ }^{89,90}$ This index consists of 5 grades of increasing disease recurrence severity, between i0 and i4, as assessed by the number and nature of ulcers in the distal ileum. The Post-operative Endoscopic Index has gained popularity because its assessment of disease recurrence predicts symptom recurrence. The remission target is a grade $<\mathrm{i} 2 .^{3}$ 
2 For endoscopic reporting of Crohn's disease activity in clinical practice, we

3 recommend using the SES-CD, or at the very least reporting, for each bowel section,

4 the presence or absence of ulcers, stenosis and the proportion of surface area

5 affected. For postoperative assessment of disease recurrence following ileocolic

6 resection, we recommend Rutgeerts' score.

7

8 [H3]Histological assessment of disease activity.

9 Histological disease activity assessment in Crohn's disease is difficult because

10 inflammation is discontinuous, transmural and can exist beyond the reach of the

11 endoscope. ${ }^{5,35}$ Targeted mucosal biopsies can be used in an attempt to limit

12 sampling error, but transmural inflammation can only be assessed in specimens

13 obtained during surgical resection. Thus, histological scoring systems for mucosal

14 biopsy samples are challenging both to develop and to use in practice. ${ }^{91}$

15 Nevertheless, microscopic inflammation can persist in biopsy samples from tissue

16 that appears quiescent when observed endoscopically, ${ }^{29,92,93}$ and some limited

17 evidence suggests that presence of microscopic inflammation is associated with increased rates of clinical relapse, stricture formation and surgery. ${ }^{29}$

20 Several histological scoring systems have been proposed for assessing Crohn's

21 disease activity (see Supplementary information S1 (table 2) online), the best known

22 of which are the Colonic and Ileal Global Histologic Disease Activity Scores (CGHAS 23 and IGHAS) (see Supplementary information S2 (table 24) online). ${ }^{91,94,95}$ Due to the

24 complexity of these scoring systems and lack of evidence correlating histological 25 disease activity with disease outcomes in Crohn's disease, we do not recommend 
1 routine use of such scoring in clinical practice. Rather, the presence of histological

2 inflammation in endoscopically quiescent disease should caution against de-

3 escalation of therapy. ${ }^{5}$

5 [H3]Radiological assessment of disease activity.

6 Given that transmural inflammation in Crohn's disease can extend beyond the reach

7 of endoscopy, imaging has an important role in assessing disease activity. ${ }^{42}$ Imaging

8 also enables evaluation of the complications of Crohn's disease, including stricturing

9 disease, fistulae and abscesses. ${ }^{96} \mathrm{MRI}$ is the preferred modality for assessing

10 extraluminal complications of Crohn's disease and the presence and severity of

11 perianal fistulae in particular. MRI and ultrasonography are the preferred modalities

12 for assessing luminal disease activity and strictures in Crohn's disease. ${ }^{42}$

14 Although the overall accuracy of CT, ultrasonography and MRI for assessing luminal 15 disease activity in Crohn's disease is similar, ${ }^{42,96}$ radiation exposure limits the use of $16 \mathrm{CT}$, which is particularly relevant to younger patients who might be exposed to a 17 substantial cumulative radiation dose over their disease course. CT is therefore not the first-choice imaging technique for assessing disease activity in Crohn's disease; when MRI and ultrasonography are unavailable, low-dose CT can be an alternative. ${ }^{97}$ Plain film radiography and barium contrast studies now have little role in Crohn's disease, due to their limited sensitivity for assessing activity in comparison

22 to MRI, CT and ultrasonography. ${ }^{42}$

Intestinal MRI requires rapid image acquisition and luminal distension for accurate assessment of disease distribution and activity, which can be achieved with a neutral 
1 contrast agent delivered via enterography or enteroclysis. ${ }^{98}$ Amongst the available

2 scoring systems (see Supplementary information S1 (table 2) online), the Magnetic

3 Resonance Index of Activity (MaRIA) is best-validated for assessment of disease

4 activity in CD and we recommend its use in clinical practice (see Supplementary

5 information S2 (table 25) online). ${ }^{99,100}$ The MaRIA correlates well with CDEIS scores

6 assessed by ileocolonoscopy $(r=0.83, P<0.001),{ }^{99}$ and has been shown to be

7 reliable in assessing disease response to therapy in Crohn's disease (90\% accuracy

8 for detecting ulcer healing and $83 \%$ accuracy for detecting endoscopic remission as

9 assessed using CDEIS). ${ }^{101}$ Although MRI is expensive in comparison to other

10 imaging modalities, the technique is cost-effective compared with CT in patients

11 younger than 50 years old, based on quality-adjusted life-year data factoring in

12 radiation exposure. ${ }^{102}$

$14 \mathrm{MRI}$ is a widely used and accurate tool to assess the presence and severity of 15 perianal fistulizing disease ${ }^{42}$. The Van Assche MRI-based score for assessing the 16 severity of perianal Crohn's disease, ${ }^{103}$ based on the classification of perianal fistula 17 developed at St. Mark's Hospital, Harrow, UK ${ }^{104}$, is useful for formal assessment of response of fistulizing disease to therapy (see Supplementary information S2 (table 26)). The score incorporates criteria relating to the local extension of fistulae, as well as active inflammation, and it demonstrates good inter-observer agreement and 21 responsiveness following anti-TNF therapy. ${ }^{103}$ The score is useful for clinical trials, but has less utility in clinical practice due to its relative complexity compared with other scores. 
1 Doppler ultrasonography is helpful in assessing disease activity, based on intestinal

2 wall thickness and intensity of flow. ${ }^{105-107}$ Although there are several scoring

3 systems for ultrasonographic assessment of disease activity (see Supplementary

4 information S1 (table 2) online), the most widely used of which is the Limberg Score

5 (see Supplementary information S2 (table 27) online), ${ }^{108}$ none of these indices have

6 been validated. Small studies $(n=24-110)$ have shown that ultrasonography is

7 responsive to improvements in disease activity following therapy, ${ }^{109-112}$ and might be

8 useful for disease monitoring after surgical resection. ${ }^{113,114}$ Point-of-care

9 ultrasonography has also been shown to influence clinical decision-making,

10 particularly when patients are asymptomatic but ultrasonography reveals evidence of

11 active disease. ${ }^{115}$ Despite promising data, the use of ultrasonography remains

12 limited by the availability of an experienced bowel sonographer. Outside Europe,

13 ultrasonography has been less commonly used, with cross-sectional imaging (CT

14 and MRI) favoured for its reproducible protocols and capacity for archival images.

15 However, as clinician awareness of the imperative for close monitoring of IBD

16 disease activity as a part of a 'treat to target' management strategy grows,

17 ultrasonography is becoming increasingly appealing as a cheap and noninvasive

18 tool, and its use is burgeoning in countries such as Australia. ${ }^{51}$

20 [H3]Biomarkers to assess disease activity.

21 Biomarkers are a noninvasive adjunct to endoscopy and cross-sectional imaging for monitoring disease activity in Crohn's disease. ${ }^{3}$ Plasma levels of CRP and faecal calprotectin are the most useful biomarkers in clinical practice. 
1 An improvement in plasma CRP levels (that is, a reduced plasma concentration of

2 CRP) has been shown to correlate with a clinical therapeutic response in Crohn's

3 disease. ${ }^{116-122}$ An elevated plasma CRP level predicts clinical relapse in Crohn's

4 disease, ${ }^{123,124}$ in both asymptomatic patients, ${ }^{125}$ as well as following withdrawal of

5 therapy. ${ }^{126-128}$ Higher plasma CRP levels prior to treatment have been shown to

6 predict an increased likelihood of maintenance of remission following anti-TNF

7 therapy. ${ }^{129}$ However, CRP level correlates only modestly with endoscopic disease

8 activity in Crohn's disease ${ }^{70,71,130-133}$, and a normal plasma CRP concentration has

9 been reported in patients with active disease, particularly those with predominantly

10 ileal rather than predominantly colonic pathology. ${ }^{134-136}$ The converse is also true, as

11 an elevated CRP level does not always correlate with active disease. ${ }^{130}$ Plasma CRP

12 concentration is therefore not a target of therapy, but rather a tool to monitor

13 inflammation to guide the necessity of radiological or endoscopic activity

14 assessment.

16 Faecal calprotectin level has been shown to correlate with endoscopic and MRI-

17 based assessment of disease activity in Crohn's disease, ${ }^{131,137-139}$ and to predict disease relapse. ${ }^{65,68,140,141}$ Levels of faecal calprotectin are also useful in monitoring

19 disease activity following initiation of therapy, ${ }^{122}$ as well as in the post-operative

20 Crohn's disease setting. ${ }^{136,142}$ However, faecal calprotectin concentration is less

21 accurate for ileal than colonic disease, and can be normal even in the presence of

22 large ulcers. ${ }^{143}$ Faecal calprotectin level cut-off values for predicting remission vary

23 widely between studies (from $<50 \mu \mathrm{g} / \mathrm{g}$ to $<250 \mu \mathrm{g} / \mathrm{g}$ ) and are only moderately

24 predictive for individual patients, ${ }^{71}$ unless a stringent cut-off value is used (such as

$25<50 \mu \mathrm{g} / \mathrm{g}$ ), which comes at the expense of sensitivity or unnecessary investigations. 
1 Thus, as for ulcerative colitis, it seems that the change in faecal calprotectin level,

2 rather than the absolute level in an individual patient, is best used in clinical practice

3 to aid treatment decision-making.

4

$5 \quad[\mathrm{H} 3] \mathrm{QOL}$

6 The three QOL questionnaires that we recommend for use in clinical practice and the

7 rationale behind these choices are the same as those used in ulcerative colitis: either

$8 \quad$ IBD-Control $^{75}$ (see Supplementary information S2 (table 15) online), the SIBDQ ${ }^{76}$

9 (see Supplementary information S2 (table 16) online) or the CUCQ-8 ${ }^{77}$ (see

10 Supplementary information S2 (table 17) online).

11

12 


\section{1 [H1]Conclusions}

2 The overarching goal of therapy in IBD is to modify the disease course to improve

3 QOL and avoid disability, whilst balancing the risks associated with therapy. ${ }^{144,145}$ To

4 reach this goal, therapy must be directed to achieve resolution of both objective

5 inflammation and clinical symptoms, as well as normalization of QOL. This 'treat to

6 target' approach requires a clinician to look beyond clinical symptoms and to assess

7 disease activity as objectively as possible. This method enables a composite

8 appraisal of the measurable burden of inflammation, the burden of disease on the

9 patient and the cumulative complications of disease over its course. ${ }^{145}$

11 Despite the disparity between clinical and objective measures of inflammation in IBD,

12 both are important when assessing disease activity. The objective burden of

13 inflammation denotes risk of negative disease outcomes in IBD, whilst clinicians

14 realize that symptoms and QOL are most important to patients. Amongst the

15 confusing myriad of disease activity indices within each domain of assessment, this

16 Review has collected and appraised the most practical and relevant indices for

17 clinical practice, augmented by supplementary tables to provide a comprehensive overview. Current indices need to be validated according to well-established statistical criteria. The metrics will help with clinical decision-making and encourage

20 physicians to strive for appropriate treatment targets that can be expected to improve 21 outcomes for people with IBD. 


\section{References}

21 Dignass, A. et al. Second European evidence-based consensus on the diagnosis and

2 Dignass, A. et al. The second European evidence-based Consensus on the diagnosis colitis 4, 28-62, doi:10.1016/j.crohns.2009.12.002 (2010).

3
Peyrin-Biroulet, L. et al. Selecting Therapeutic Targets in Inflammatory Bowel Disease (STRIDE): Determining Therapeutic Goals for Treat-to-Target. The American journal of gastroenterology 110, 1324-1338, doi:10.1038/ajg.2015.233 (2015).

4 Walsh, A. J. et al. Comparing disease activity indices in ulcerative colitis. Journal of Crohn's \& colitis 8, 318-325, doi:10.1016/j.crohns.2013.09.010 (2014).

5 Bryant, R. V., Winer, S., Travis, S. P. \& Riddell, R. H. Systematic review: histological remission in inflammatory bowel disease. Is 'complete' remission the new treatment paradigm? An IOIBD initiative. Journal of Crohn's \& colitis 8, 1582-1597, doi:10.1016/j.crohns.2014.08.011 (2014).

6 Marchal-Bressenot, A. et al. Development and validation of the Nancy histological index for UC. Gut, doi:10.1136/gutjnl-2015-310187 (2015).

7 Travis, S. P. et al. Once-daily budesonide MMX in active, mild-to-moderate ulcerative colitis: results from the randomised CORE II study. Gut 63, 433-441, doi:10.1136/gutjnl-2012-304258 (2014).

8 Travis, S. P. et al. Developing an instrument to assess the endoscopic severity of ulcerative colitis: the Ulcerative Colitis Endoscopic Index of Severity (UCEIS). Gut 61, 535-542, doi:10.1136/gutjnl-2011-300486 (2012).

9 Travis, S. P. et al. Reliability and initial validation of the ulcerative colitis endoscopic index of severity. Gastroenterology 145, 987-995, doi:10.1053/j.gastro.2013.07.024 (2013).

10 Walmsley, R. S., Ayres, R. C., Pounder, R. E. \& Allan, R. N. A simple clinical colitis activity index. Gut 43, 29-32 (1998).

11 Schroeder, K. W., Tremaine, W. J. \& Ilstrup, D. M. Coated oral 5-aminosalicylic acid therapy for mildly to moderately active ulcerative colitis. A randomized study. The New England journal of medicine 317, 1625-1629, doi:10.1056/nejm198712243172603 (1987).

12 Sandborn, W. J. et al. Repifermin (keratinocyte growth factor-2) for the treatment of active ulcerative colitis: a randomized, double-blind, placebo-controlled, doseescalation trial. Alimentary pharmacology \& therapeutics 17, 1355-1364 (2003).

13 Turner, D. et al. Development, validation, and evaluation of a pediatric ulcerative colitis activity index: a prospective multicenter study. Gastroenterology 133, 423432, doi:10.1053/j.gastro.2007.05.029 (2007).

14 Truelove, S. C. \& Witts, L. J. Cortisone in ulcerative colitis; final report on a therapeutic trial. British medical journal 2, 1041-1048 (1955).

15 Turner, D. et al. A systematic prospective comparison of noninvasive disease activity indices in ulcerative colitis. Clinical gastroenterology and hepatology : the official clinical practice journal of the American Gastroenterological Association 7, 10811088, doi:10.1016/j.cgh.2009.06.024 (2009). 
16 D'Haens, G. et al. A review of activity indices and efficacy end points for clinical trials of medical therapy in adults with ulcerative colitis. Gastroenterology 132, 763-786, doi:10.1053/j.gastro.2006.12.038 (2007).

17 Dignass, A. et al. Second European evidence-based consensus on the diagnosis and management of ulcerative colitis part 1: definitions and diagnosis. Journal of Crohn's \& colitis 6, 965-990, doi:10.1016/j.crohns.2012.09.003 (2012).

18 Dinesen, L. C. et al. The pattern and outcome of acute severe colitis. Journal of Crohn's \& colitis 4, 431-437, doi:10.1016/j.crohns.2010.02.001 (2010).

19 Neurath, M. F. \& Travis, S. P. Mucosal healing in inflammatory bowel diseases: a systematic review. Gut 61, 1619-1635, doi:10.1136/gutjnl-2012-302830 (2012).

20 Sandborn, W. J. et al. A review of activity indices and efficacy endpoints for clinical trials of medical therapy in adults with Crohn's disease. Gastroenterology 122, 512530 (2002).

21 Froslie, K. F., Jahnsen, J., Moum, B. A. \& Vatn, M. H. Mucosal healing in inflammatory bowel disease: results from a Norwegian population-based cohort. Gastroenterology 133, 412-422, doi:10.1053/j.gastro.2007.05.051 (2007).

22 Ardizzone, S. et al. Randomised controlled trial of azathioprine and 5-aminosalicylic acid for treatment of steroid dependent ulcerative colitis. Gut 55, 47-53, doi:10.1136/gut.2005.068809 (2006).

23 Rutgeerts, P. et al. Scheduled maintenance treatment with infliximab is superior to episodic treatment for the healing of mucosal ulceration associated with Crohn's disease. Gastrointestinal endoscopy 63, 433-442; quiz 464, doi:10.1016/j.gie.2005.08.011 (2006).

24 Schnitzler, F. et al. Mucosal healing predicts long-term outcome of maintenance therapy with infliximab in Crohn's disease. Inflammatory bowel diseases 15, 12951301, doi:10.1002/ibd.20927 (2009).

25 Colombel, J. F. et al. Early mucosal healing with infliximab is associated with improved long-term clinical outcomes in ulcerative colitis. Gastroenterology 141, 1194-1201, doi:10.1053/j.gastro.2011.06.054 (2011).

26 Rutter, M. et al. Severity of inflammation is a risk factor for colorectal neoplasia in ulcerative colitis. Gastroenterology 126, 451-459 (2004).

27 Corte, C. J. et al. Association between the Ulcerative Colitis Endoscopic Index of Severity (UCEIS) and outcomes in acute severe ulcerative colitis. Journal of Crohn's \& colitis, doi:10.1093/ecco-jcc/jjv047 (2015).

28 Ikeya, K. et al. The Ulcerative Colitis Endoscopic Index of Severity More Accurately Reflects Clinical Outcomes and Long-term Prognosis than the Mayo Endoscopic Score. Journal of Crohn's \& colitis, doi:10.1093/ecco-jcc/jjv210 (2015).

29 Baars, J. E., Nuij, V. J., Oldenburg, B., Kuipers, E. J. \& van der Woude, C. J. Majority of patients with inflammatory bowel disease in clinical remission have mucosal inflammation. Inflammatory bowel diseases 18, 1634-1640, doi:10.1002/ibd.21925 (2012).

30 Bessissow, T. et al. Prognostic value of serologic and histologic markers on clinical relapse in ulcerative colitis patients with mucosal healing. The American journal of gastroenterology 107, 1684-1692, doi:10.1038/ajg.2012.301 (2012).

31 Bitton, A. et al. Clinical, biological, and histologic parameters as predictors of relapse in ulcerative colitis. Gastroenterology 120, 13-20 (2001). 
32 Bryant, R. V. et al. Beyond endoscopic mucosal healing in UC: histological remission better predicts corticosteroid use and hospitalisation over 6 years of follow-up. Gut, doi:10.1136/gutjnl-2015-309598 (2015).

33 Gupta, R. B. et al. Histologic inflammation is a risk factor for progression to colorectal neoplasia in ulcerative colitis: a cohort study. Gastroenterology 133, 1099-1105; quiz 1340-1091, doi:10.1053/j.gastro.2007.08.001 (2007).

34 Mosli, M. H. et al. Development and validation of a histological index for UC. Gut, doi:10.1136/gutjnl-2015-310393 (2015).

35 Magro, F. et al. European consensus on the histopathology of inflammatory bowel disease. Journal of Crohn's \& colitis 7, 827-851, doi:10.1016/j.crohns.2013.06.001 (2013).

36 Mosli, M. H. et al. Reproducibility of histological assessments of disease activity in UC. Gut 64, 1765-1773, doi:10.1136/gutjnl-2014-307536 (2015).

37 Bressenot, A. et al. Comparing histological activity indexes in UC. Gut, doi:10.1136/gutjnl-2014-307477 (2014).

38 Riley, S. A., Mani, V., Goodman, M. J., Dutt, S. \& Herd, M. E. Microscopic activity in ulcerative colitis: what does it mean? Gut 32, 174-178 (1991).

39 Geboes, K. et al. A reproducible grading scale for histological assessment of inflammation in ulcerative colitis. Gut 47, 404-409 (2000).

40 Azad, S., Sood, N. \& Sood, A. Biological and histological parameters as predictors of relapse in ulcerative colitis: a prospective study. Saudi journal of gastroenterology: official journal of the Saudi Gastroenterology Association 17, 194-198, doi:10.4103/1319-3767.80383 (2011).

41 Feagan, B. G. et al. Treatment of ulcerative colitis with a humanized antibody to the alpha4beta7 integrin. The New England journal of medicine 352, 2499-2507, doi:10.1056/NEJMoa042982 (2005).

42 Panes, J. et al. Imaging techniques for assessment of inflammatory bowel disease: joint ECCO and ESGAR evidence-based consensus guidelines. Journal of Crohn's \& colitis 7, 556-585, doi:10.1016/j.crohns.2013.02.020 (2013).

43 Benchimol, E. I. et al. Toxic megacolon in children with inflammatory bowel disease: clinical and radiographic characteristics. The American journal of gastroenterology 103, 1524-1531, doi:10.1111/j.1572-0241.2008.01807.x (2008).

44 Allison, M. C. \& Vallance, R. Prevalence of proximal faecal stasis in active ulcerative colitis. Gut 32, 179-182 (1991).

45 Fletcher, J. G., Fidler, J. L., Bruining, D. H. \& Huprich, J. E. New concepts in intestinal imaging for inflammatory bowel diseases. Gastroenterology 140, 1795-1806, doi:10.1053/j.gastro.2011.02.013 (2011).

46 Yarur, A. J. et al. Predictive factors for clinically actionable computed tomography findings in inflammatory bowel disease patients seen in the emergency department with acute gastrointestinal symptoms. Journal of Crohn's \& colitis 8, 504-512, doi:10.1016/j.crohns.2013.11.003 (2014).

47 Ordas, I. et al. Diagnostic accuracy of magnetic resonance colonography for the evaluation of disease activity and severity in ulcerative colitis: a prospective study. Gut 62, 1566-1572, doi:10.1136/gutjnl-2012-303240 (2013).

48 Oussalah, A. et al. Diffusion-weighted magnetic resonance without bowel preparation for detecting colonic inflammation in inflammatory bowel disease. Gut 59, 1056-1065, doi:10.1136/gut.2009.197665 (2010). 
49 Parente, F. et al. Are colonoscopy and bowel ultrasound useful for assessing response to short-term therapy and predicting disease outcome of moderate-tosevere forms of ulcerative colitis?: a prospective study. The American journal of gastroenterology 105, 1150-1157, doi:10.1038/ajg.2009.672 (2010).

50 Parente, F. A., S.; Greco, S.; et al. Response to high-dose steroids of severe attacks of ulcerative colitis may rely on bowel ultrasound instead of colonoscopy. A preliminary study. Gut 55 A118 (2006).

51 Asthana, A. K. et al. Failure of gastroenterologists to apply intestinal ultrasound in inflammatory bowel disease in the Asia-Pacific: a need for action. Journal of gastroenterology and hepatology 30, 446-452, doi:10.1111/jgh.12871 (2015).

52 Solem, C. A. et al. Correlation of C-reactive protein with clinical, endoscopic, histologic, and radiographic activity in inflammatory bowel disease. Inflammatory bowel diseases 11, 707-712 (2005).

53 Osada, T. et al. Correlations among total colonoscopic findings, clinical symptoms, and laboratory markers in ulcerative colitis. Journal of gastroenterology and hepatology 23 Suppl 2, S262-267, doi:10.1111/j.1440-1746.2008.05413.x (2008).

54 Turner, D. et al. Severe pediatric ulcerative colitis: a prospective multicenter study of outcomes and predictors of response. Gastroenterology 138, 2282-2291, doi:10.1053/j.gastro.2010.02.047 (2010).

55 Travis, S. P. et al. Predicting outcome in severe ulcerative colitis. Gut 38, 905-910 (1996).

56 Kumar, S., Ghoshal, U. C., Aggarwal, R., Saraswat, V. A. \& Choudhuri, G. Severe ulcerative colitis: prospective study of parameters determining outcome. Journal of gastroenterology and hepatology 19, 1247-1252, doi:10.1111/j.14401746.2004.03486.x (2004).

57 Aceituno, M. et al. Steroid-refractory ulcerative colitis: predictive factors of response to cyclosporine and validation in an independent cohort. Inflammatory bowel diseases 14, 347-352, doi:10.1002/ibd.20322 (2008).

58 Cesarini, M. C., G.; Ronnblom, A.; Santos, A.; Sjoberg, D.; Parkes, M.; Keshav, S.; Travis, SPL. P079. Predicting the risk of acute severe colitis (ASC) at diagnosis of Ulcerative Colitis (UC): external validation. Journal of Crohn's \& colitis 9 Suppl 1, S117-118, doi:10.1093/ecco-jcc/jju027.197 (2015).

59 Henriksen, M. et al. C-reactive protein: a predictive factor and marker of inflammation in inflammatory bowel disease. Results from a prospective populationbased study. Gut 57, 1518-1523, doi:10.1136/gut.2007.146357 (2008).

60 Yoon, J. Y. et al. Correlations of C-reactive protein levels and erythrocyte sedimentation rates with endoscopic activity indices in patients with ulcerative colitis. Digestive diseases and sciences 59, 829-837, doi:10.1007/s10620-013-2907-3 (2014).

61 Guardiola, J. et al. Fecal level of calprotectin identifies histologic inflammation in patients with ulcerative colitis in clinical and endoscopic remission. Clinical gastroenterology and hepatology : the official clinical practice journal of the American Gastroenterological Association 12, 1865-1870, doi:10.1016/j.cgh.2014.06.020 (2014).

62 Yamaguchi, S. et al. Fecal calprotectin is a clinically relevant biomarker of mucosal healing in patients with quiescent ulcerative colitis. Journal of gastroenterology and hepatology, doi:10.1111/jgh.13061 (2015). 
Theede, K. et al. Level of Fecal Calprotectin Correlates With Endoscopic and Histologic Inflammation and Identifies Patients With Mucosal Healing in Ulcerative Colitis. Clinical gastroenterology and hepatology : the official clinical practice journal of the American Gastroenterological Association 13, 1929-1936.e1921, doi:10.1016/j.cgh.2015.05.038 (2015).

64 Yamamoto, T., Shiraki, M., Bamba, T., Umegae, S. \& Matsumoto, K. Fecal calprotectin and lactoferrin as predictors of relapse in patients with quiescent ulcerative colitis during maintenance therapy. International journal of colorectal disease 29, 485-491, doi:10.1007/s00384-013-1817-3 (2014).

65 Gisbert, J. P. et al. Fecal calprotectin and lactoferrin for the prediction of inflammatory bowel disease relapse. Inflammatory bowel diseases 15, 1190-1198, doi:10.1002/ibd.20933 (2009).

66 De Vos, M. et al. Consecutive fecal calprotectin measurements to predict relapse in patients with ulcerative colitis receiving infliximab maintenance therapy. Inflammatory bowel diseases 19, 2111-2117, doi:10.1097/MIB.0b013e31829b2a37 (2013).

67 Molander, P. et al. Fecal calprotectin concentration predicts outcome in inflammatory bowel disease after induction therapy with TNFalpha blocking agents. Inflammatory bowel diseases 18, 2011-2017, doi:10.1002/ibd.22863 (2012).

68 Molander, P. et al. Does fecal calprotectin predict short-term relapse after stopping TNFalpha-blocking agents in inflammatory bowel disease patients in deep remission? Journal of Crohn's \& colitis 9, 33-40, doi:10.1016/j.crohns.2014.06.012 (2015).

69 Osterman, M. T. et al. Mesalamine dose escalation reduces fecal calprotectin in patients with quiescent ulcerative colitis. Clinical gastroenterology and hepatology: the official clinical practice journal of the American Gastroenterological Association 12, 1887-1893.e1883, doi:10.1016/j.cgh.2014.03.035 (2014).

70 Falvey, J. D. et al. Disease activity assessment in IBD: clinical indices and biomarkers fail to predict endoscopic remission. Inflammatory bowel diseases 21, 824-831, doi:10.1097/mib.0000000000000341 (2015).

71 Mosli, M. H. et al. C-Reactive Protein, Fecal Calprotectin, and Stool Lactoferrin for Detection of Endoscopic Activity in Symptomatic Inflammatory Bowel Disease Patients: A Systematic Review and Meta-Analysis. The American journal of gastroenterology 110, 802-819; quiz 820, doi:10.1038/ajg.2015.120 (2015).

72 Calafat, M. et al. High within-day variability of fecal calprotectin levels in patients with active ulcerative colitis: what is the best timing for stool sampling? Inflammatory bowel diseases 21, 1072-1076, doi:10.1097/mib.0000000000000349 (2015).

73 Kristensen, V. et al. Prediction of endoscopic disease activity in ulcerative colitis by two different assays for fecal calprotectin. Journal of Crohn's \& colitis 9, 164-169, doi:10.1093/ecco-jcc/jju015 (2015).

74 Guyatt, G. et al. A new measure of health status for clinical trials in inflammatory bowel disease. Gastroenterology 96, 804-810 (1989).

75 Bodger, K., Ormerod, C., Shackcloth, D. \& Harrison, M. Development and validation of a rapid, generic measure of disease control from the patient's perspective: the IBD-control questionnaire. Gut 63, 1092-1102, doi:10.1136/gutjnl-2013-305600 (2014). 
17 Irvine, E. J., Zhou, Q. \& Thompson, A. K. The Short Inflammatory Bowel Disease Questionnaire: a quality of life instrument for community physicians managing inflammatory bowel disease. CCRPT Investigators. Canadian Crohn's Relapse Prevention Trial. The American journal of gastroenterology 91, 1571-1578 (1996).

77 Alrubaiy, L. et al. Development of a short questionnaire to assess the quality of life in Crohn's disease and ulcerative colitis. Journal of Crohn's \& colitis 9, 66-76, doi:10.1093/ecco-jcc/jju005 (2015).

78 Jowett, S. L., Seal, C. J., Barton, J. R. \& Welfare, M. R. The short inflammatory bowel disease questionnaire is reliable and responsive to clinically important change in ulcerative colitis. The American journal of gastroenterology 96, 2921-2928, doi:10.1111/j.1572-0241.2001.04682.x (2001).

79 Seagrove, A. C. et al. Randomised controlled trial. Comparison Of iNfliximab and ciclosporin in STeroid Resistant Ulcerative Colitis: Trial design and protocol (CONSTRUCT). BMJ open 4, e005091, doi:10.1136/bmjopen-2014-005091 (2014).

80 Best, W. R., Becktel, J. M., Singleton, J. W. \& Kern, F., Jr. Development of a Crohn's disease activity index. National Cooperative Crohn's Disease Study. Gastroenterology 70, 439-444 (1976).

81 Sands, B. E. \& Ooi, C. J. A survey of methodological variation in the Crohn's disease activity index. Inflammatory bowel diseases 11, 133-138 (2005).

82 Harvey, R. F. \& Bradshaw, J. M. A simple index of Crohn's-disease activity. Lancet 1, 514 (1980).

83 Vermeire, S., Schreiber, S., Sandborn, W. J., Dubois, C. \& Rutgeerts, P. Correlation between the Crohn's disease activity and Harvey-Bradshaw indices in assessing Crohn's disease severity. Clinical gastroenterology and hepatology : the official clinical practice journal of the American Gastroenterological Association 8, 357-363, doi:10.1016/j.cgh.2010.01.001 (2010).

84 Irvine, E. J. Usual therapy improves perianal Crohn's disease as measured by a new disease activity index. McMaster IBD Study Group. Journal of clinical gastroenterology 20, 27-32 (1995).

85 D'Haens, G. R. et al. Endpoints for clinical trials evaluating disease modification and structural damage in adults with Crohn's disease. Inflammatory bowel diseases 15, 1599-1604, doi:10.1002/ibd.21034 (2009).

86 De Cruz, P., Kamm, M. A., Prideaux, L., Allen, P. B. \& Moore, G. Mucosal healing in Crohn's disease: a systematic review. Inflammatory bowel diseases 19, 429-444, doi:10.1002/ibd.22977 (2013).

87 Mary, J. Y. \& Modigliani, R. Development and validation of an endoscopic index of the severity for Crohn's disease: a prospective multicentre study. Groupe d'Etudes Therapeutiques des Affections Inflammatoires du Tube Digestif (GETAID). Gut 30, 983-989 (1989).

88 Daperno, M. et al. Development and validation of a new, simplified endoscopic activity score for Crohn's disease: the SES-CD. Gastrointestinal endoscopy 60, 505512 (2004).

89 Rutgeerts, P. et al. Predictability of the postoperative course of Crohn's disease. Gastroenterology 99, 956-963 (1990).

90 Rutgeerts, P. et al. Natural history of recurrent Crohn's disease at the ileocolonic anastomosis after curative surgery. Gut 25, 665-672 (1984). 
91 D'Haens, G. R. et al. Early lesions of recurrent Crohn's disease caused by infusion of intestinal contents in excluded ileum. Gastroenterology 114, 262-267 (1998).

92 Korelitz, B. I. \& Sommers, S. C. Response to drug therapy in Crohn's disease: evaluation by rectal biopsy and mucosal cell counts. Journal of clinical gastroenterology 6, 123-127 (1984).

93 Molander, P. et al. Achievement of deep remission during scheduled maintenance therapy with TNFalpha-blocking agents in IBD. Journal of Crohn's \& colitis 7, 730-735, doi:10.1016/j.crohns.2012.10.018 (2013).

94 D'Haens, G. et al. Endoscopic and histological healing with infliximab anti-tumor necrosis factor antibodies in Crohn's disease: A European multicenter trial. Gastroenterology 116, 1029-1034 (1999).

95 Geboes, K. et al. Endoscopic and histologic evidence of persistent mucosal healing and correlation with clinical improvement following sustained infliximab treatment for Crohn's disease. Current medical research and opinion 21, 1741-1754, doi:10.1185/030079905x65457 (2005).

96 Panes, J. et al. Systematic review: the use of ultrasonography, computed tomography and magnetic resonance imaging for the diagnosis, assessment of activity and abdominal complications of Crohn's disease. Alimentary pharmacology \& therapeutics 34, 125-145, doi:10.1111/j.1365-2036.2011.04710.x (2011).

97 Craig, O. et al. Diagnostic accuracy of computed tomography using lower doses of radiation for patients with Crohn's disease. Clinical gastroenterology and hepatology : the official clinical practice journal of the American Gastroenterological Association 10, 886-892, doi:10.1016/j.cgh.2012.03.014 (2012).

98 Kuehle, C. A. et al. Hydro-MRI of the small bowel: effect of contrast volume, timing of contrast administration, and data acquisition on bowel distention. AJR. American journal of roentgenology 187, W375-385, doi:10.2214/ajr.05.1079 (2006).

99 Rimola, J. et al. Magnetic resonance imaging for evaluation of Crohn's disease: validation of parameters of severity and quantitative index of activity. Inflammatory bowel diseases 17, 1759-1768, doi:10.1002/ibd.21551 (2011).

100 Rimola, J. et al. Magnetic resonance for assessment of disease activity and severity in ileocolonic Crohn's disease. Gut 58, 1113-1120, doi:10.1136/gut.2008.167957 (2009).

101 Ordas, l. et al. Accuracy of magnetic resonance enterography in assessing response to therapy and mucosal healing in patients with Crohn's disease. Gastroenterology 146, 374-382.e371, doi:10.1053/j.gastro.2013.10.055 (2014).

102 Cipriano, L. E., Levesque, B. G., Zaric, G. S., Loftus, E. V., Jr. \& Sandborn, W. J. Costeffectiveness of imaging strategies to reduce radiation-induced cancer risk in Crohn's disease. Inflammatory bowel diseases 18, 1240-1248, doi:10.1002/ibd.21862 (2012).

103 Van Assche, G. et al. Magnetic resonance imaging of the effects of infliximab on perianal fistulizing Crohn's disease. The American journal of gastroenterology 98, 332-339, doi:10.1111/j.1572-0241.2003.07241.x (2003).

104 Parks, A. G., Gordon, P. H. \& Hardcastle, J. D. A classification of fistula-in-ano. The British journal of surgery 63, 1-12 (1976).

105 Martinez, M. J., Ripolles, T., Paredes, J. M., Blanc, E. \& Marti-Bonmati, L. Assessment of the extension and the inflammatory activity in Crohn's disease: comparison of ultrasound and MRI. Abdominal imaging 34, 141-148, doi:10.1007/s00261-0089365-y (2009). 
106 Migaleddu, V. et al. Contrast-enhanced ultrasonographic evaluation of inflammatory activity in Crohn's disease. Gastroenterology 137, 43-52, doi:10.1053/j.gastro.2009.03.062 (2009).

107 Neye, H. et al. Evaluation of criteria for the activity of Crohn's disease by power Doppler sonography. Digestive diseases (Basel, Switzerland) 22, 67-72, doi:10.1159/000078737 (2004).

108 Limberg, B. [Diagnosis of chronic inflammatory bowel disease by ultrasonography]. Zeitschrift fur Gastroenterologie 37, 495-508 (1999).

109 Paredes, J. M. et al. Abdominal sonographic changes after antibody to tumor necrosis factor (anti-TNF) alpha therapy in Crohn's Disease. Digestive diseases and sciences 55, 404-410, doi:10.1007/s10620-009-0759-7 (2010).

110 Calabrese, E. et al. Development of a numerical index quantitating small bowel damage as detected by ultrasonography in Crohn's disease. Journal of Crohn's \& colitis 6, 852-860, doi:10.1016/j.crohns.2012.01.015 (2012).

111 Moreno, N. et al. Usefulness of abdominal ultrasonography in the analysis of endoscopic activity in patients with Crohn's disease: changes following treatment with immunomodulators and/or anti-TNF antibodies. Journal of Crohn's \& colitis 8, 1079-1087, doi:10.1016/j.crohns.2014.02.008 (2014).

112 Zorzi, F. et al. A sonographic lesion index for Crohn's disease helps monitor changes in transmural bowel damage during therapy. Clinical gastroenterology and hepatology : the official clinical practice journal of the American Gastroenterological Association 12, 2071-2077, doi:10.1016/j.cgh.2014.04.036 (2014).

113 Calabrese, E. et al. Accuracy of small-intestine contrast ultrasonography, compared with computed tomography enteroclysis, in characterizing lesions in patients with Crohn's disease. Clinical gastroenterology and hepatology : the official clinical practice journal of the American Gastroenterological Association 11, 950-955, doi:10.1016/j.cgh.2013.01.015 (2013).

114 Castiglione, F. et al. Oral contrast-enhanced sonography for the diagnosis and grading of postsurgical recurrence of Crohn's disease. Inflammatory bowel diseases 14, 1240-1245, doi:10.1002/ibd.20469 (2008).

115 Novak, K. et al. Clinic-based Point of Care Transabdominal Ultrasound for Monitoring Crohn's Disease: Impact on Clinical Decision Making. Journal of Crohn's \& colitis $\mathbf{9}$, 795-801, doi:10.1093/ecco-jcc/jjv105 (2015).

116 Kiss, L. S. et al. Early clinical remission and normalisation of CRP are the strongest predictors of efficacy, mucosal healing and dose escalation during the first year of adalimumab therapy in Crohn's disease. Alimentary pharmacology \& therapeutics 34, 911-922, doi:10.1111/j.1365-2036.2011.04827.x (2011).

117 Hanauer, S. B. et al. Human anti-tumor necrosis factor monoclonal antibody (adalimumab) in Crohn's disease: the CLASSIC-I trial. Gastroenterology 130, 323-333; quiz 591, doi:10.1053/j.gastro.2005.11.030 (2006).

118 Lamireau, T. et al. Efficacy and tolerance of infliximab in children and adolescents with Crohn's disease. Inflammatory bowel diseases 10, 745-750 (2004).

119 Rutgeerts, P. et al. Efficacy and safety of retreatment with anti-tumor necrosis factor antibody (infliximab) to maintain remission in Crohn's disease. Gastroenterology 117, 761-769 (1999).

120 Targan, S. R. et al. A short-term study of chimeric monoclonal antibody cA2 to tumor necrosis factor alpha for Crohn's disease. Crohn's Disease cA2 Study Group. The New 

(1997).

121 Reinisch, W. et al. Factors associated with short- and long-term outcomes of therapy for Crohn's disease. Clinical gastroenterology and hepatology : the official clinical practice journal of the American Gastroenterological Association 13, 539-547.e532, doi:10.1016/j.cgh.2014.09.031 (2015).

122 Sipponen, T. et al. Faecal calprotectin and lactoferrin are reliable surrogate markers of endoscopic response during Crohn's disease treatment. Scandinavian journal of gastroenterology 45, 325-331, doi:10.3109/00365520903483650 (2010).

123 Kiss, L. S. et al. High-sensitivity C-reactive protein for identification of disease phenotype, active disease, and clinical relapses in Crohn's disease: a marker for patient classification? Inflammatory bowel diseases 18, 1647-1654, doi:10.1002/ibd.21933 (2012).

124 Henderson, P. et al. Serum C-reactive protein and CRP genotype in pediatric inflammatory bowel disease: influence on phenotype, natural history, and response to therapy. Inflammatory bowel diseases 21, 596-605, doi:10.1097/mib.0000000000000296 (2015).

125 Click, B. et al. Silent Crohn's Disease: Asymptomatic Patients with Elevated C-reactive Protein Are at Risk for Subsequent Hospitalization. Inflammatory bowel diseases 21, 2254-2261, doi:10.1097/mib.0000000000000516 (2015).

126 Kennedy, N. A. et al. Thiopurine withdrawal during sustained clinical remission in inflammatory bowel disease: relapse and recapture rates, with predictive factors in 237 patients. Alimentary pharmacology \& therapeutics 40, 1313-1323, doi:10.1111/apt.12980 (2014).

127 Louis, E. et al. Maintenance of remission among patients with Crohn's disease on antimetabolite therapy after infliximab therapy is stopped. Gastroenterology 142, 63-70 e65; quiz e31, doi:10.1053/j.gastro.2011.09.034 (2012).

128 Treton, X. et al. Azathioprine withdrawal in patients with Crohn's disease maintained on prolonged remission: a high risk of relapse. Clinical gastroenterology and hepatology : the official clinical practice journal of the American Gastroenterological Association 7, 80-85, doi:10.1016/j.cgh.2008.08.028 (2009).

129 Reinisch, W., Wang, Y., Oddens, B. J. \& Link, R. C-reactive protein, an indicator for maintained response or remission to infliximab in patients with Crohn's disease: a post-hoc analysis from ACCENT I. Alimentary pharmacology \& therapeutics 35, 568576, doi:10.1111/j.1365-2036.2011.04987.x (2012).

130 Jones, J. et al. Relationships between disease activity and serum and fecal biomarkers in patients with Crohn's disease. Clinical gastroenterology and hepatology : the official clinical practice journal of the American Gastroenterological Association 6, 1218-1224, doi:10.1016/j.cgh.2008.06.010 (2008).

131 Zubin, G. \& Peter, L. Predicting Endoscopic Crohn's Disease Activity Before and After Induction Therapy in Children: A Comprehensive Assessment of PCDAI, CRP, and Fecal Calprotectin. Inflammatory bowel diseases 21, 1386-1391, doi:10.1097/mib.0000000000000388 (2015).

132 Chamouard, P., Richert, Z., Meyer, N., Rahmi, G. \& Baumann, R. Diagnostic value of C-reactive protein for predicting activity level of Crohn's disease. Clinical gastroenterology and hepatology : the official clinical practice journal of the 
American Gastroenterological Association 4, 882-887, doi:10.1016/j.cgh.2006.02.003 (2006).

133 Karoui, S. et al. Correlation between levels of C-reactive protein and clinical activity in Crohn's disease. Digestive and liver disease : official journal of the Italian Society of Gastroenterology and the Italian Association for the Study of the Liver 39, 1006-1010, doi:10.1016/j.dld.2007.06.015 (2007).

134 Florin, T. H., Paterson, E. W., Fowler, E. V. \& Radford-Smith, G. L. Clinically active Crohn's disease in the presence of a low C-reactive protein. Scandinavian journal of gastroenterology 41, 306-311, doi:10.1080/00365520500217118 (2006).

135 Yang, D. H. et al. Usefulness of C-reactive protein as a disease activity marker in Crohn's disease according to the location of disease. Gut and liver 9, 80-86, doi:10.5009/gnl13424 (2015).

136 Wright, E. K. et al. Measurement of fecal calprotectin improves monitoring and detection of recurrence of Crohn's disease after surgery. Gastroenterology 148, 938947 e931, doi:10.1053/j.gastro.2015.01.026 (2015).

137 Cerrillo, E. et al. Fecal Calprotectin in Ileal Crohn's Disease: Relationship with Magnetic Resonance Enterography and a Pathology Score. Inflammatory bowel diseases 21, 1572-1579, doi:10.1097/mib.0000000000000404 (2015).

138 Schoepfer, A. M. et al. Fecal calprotectin more accurately reflects endoscopic activity of ulcerative colitis than the Lichtiger Index, C-reactive protein, platelets, hemoglobin, and blood leukocytes. Inflammatory bowel diseases 19, 332-341, doi:10.1097/MIB.0b013e3182810066 (2013).

139 D'Haens, G. et al. Fecal calprotectin is a surrogate marker for endoscopic lesions in inflammatory bowel disease. Inflammatory bowel diseases 18, 2218-2224, doi:10.1002/ibd.22917 (2012).

140 Ferreiro-Iglesias, R. et al. Fecal Calprotectin as Predictor of Relapse in Patients With Inflammatory Bowel Disease Under Maintenance Infliximab Therapy. Journal of clinical gastroenterology, doi:10.1097/mcg.0000000000000312 (2015).

141 Mooiweer, E. et al. Low fecal calprotectin predicts sustained clinical remission in inflammatory bowel disease patients: a plea for deep remission. Journal of Crohn's \& colitis 9, 50-55, doi:10.1093/ecco-jcc/jju003 (2015).

142 De Cruz, P. et al. Postoperative recurrence of Crohn's disease: impact of endoscopic monitoring and treatment step-up. Colorectal disease : the official journal of the Association of Coloproctology of Great Britain and Ireland 15, 187-197, doi:10.1111/j.1463-1318.2012.03168.x (2013).

143 Gecse, K. B. et al. Impact of disease location on fecal calprotectin levels in Crohn's disease. Scandinavian journal of gastroenterology 50, 841-847, doi:10.3109/00365521.2015.1008035 (2015).

144 Allen, P. B. \& Peyrin-Biroulet, L. Moving towards disease modification in inflammatory bowel disease therapy. Current opinion in gastroenterology 29, 397404, doi:10.1097/MOG.0b013e3283622914 (2013).

145 Peyrin-Biroulet, L. et al. Defining Disease Severity in Inflammatory Bowel Diseases: Current and Future Directions. Clinical gastroenterology and hepatology : the official clinical practice journal of the American Gastroenterological Association, doi:10.1016/j.cgh.2015.06.001 (2015). 


\section{Author contributions:}

3 All authors contributed equally to this article.

4

\section{$5 \quad$ Competing interests:}

6 A.J.W.has served as an advisory board member for AbbVie, Ferring, Janssen-Cilag, Hospira 7 and Takeda. She has received honoraria for speaking from AbbVie, Ferring, Janssen-Cilag 8 and Shire, and has received grants for support of research from AbbVie, Ferring, Janssen-

9 Cilag and Shire.

R.V.B. has received conference attendance support from Ferring, Janssen, and Takeda, and

11 honoraria for speaking from Abbvie, Janssen-Cilag and Shire, , and.

12 S.P.L.T. has received grants for research support from AbbVie, Lilly, Norman Collison

13 Foundation, UCB and Vifor. He has received consulting and/or speaker fees from AbbVie,

14 Boehringer Ingelheim, Bristol-Myers Squibb, Celgene, Cosmo, Ferring, Giuliani SpA,

15 GlaxoSmithKline, Lilly, MSD, Neovacs, Novartis, Norman Collison Foundation, Novo Nordisk,

16 Pfizer, Proximagen, Receptos, Shire, Sigmoid Pharma, Takeda, TopiVert, UCB, VHsquared,

17 Vifor, and Warner Chilcott.

\section{Review criteria}

A literature search was performed to evaluate available disease activity assessment indices within each of the prescribed domains; clinical, endoscopic, histologic, and radiologic assessment, biomarkers and quality of life (See Supplementary Information S4 (box) online). 


\section{Supplementary Information}

5 See online article: S1 (tables) | S2 (tables) | S3 (file) | S4 (box)

6

Figure 1 | Domains of disease activity assessment.

Domains of disease activity assessment in IBD overlap, and consist of inflammation, 13 clinical symptoms and quality of life. Inflammation can be assessed by endoscopy, 14 histology, imaging and/or biomarkers.

17 Table 1: Ulcerative colitis disease activity assessment indices in clinical practice

19

\begin{tabular}{|c|c|c|c|c|c|c|}
\hline Domain & Index Name & Abbreviation & $\begin{array}{l}\text { Range and } \\
\text { remission } \\
\text { threshold }\end{array}$ & Strengths & Weaknesses & $\begin{array}{l}\text { Suppl. } \\
\text { Table } \\
\text { Number }\end{array}$ \\
\hline \multirow[t]{4}{*}{ Clinical } & $\begin{array}{l}\text { Simple } \\
\text { Clinical } \\
\text { Colitis } \\
\text { Activity } \\
\text { Index }{ }^{10}\end{array}$ & SCCAI & $\begin{array}{l}0-19 \\
\text { Remission: } \leq 2\end{array}$ & $\begin{array}{l}\text { Able to be } \\
\text { completed by } \\
\text { patient } \\
\text { Includes important } \\
\text { factors such as } \\
\text { urgency, } \\
\text { incontinence and } \\
\text { nocturnal bowel } \\
\text { movements } \\
\text { Reliable, valid, } \\
\text { responsive and } \\
\text { feasible }\end{array}$ & Not validated & 1 \\
\hline & $\begin{array}{l}\text { Partial Mayo } \\
\text { Index }{ }^{11,12}\end{array}$ & NA & $\begin{array}{l}0-9 \\
\text { Remission: } \leq 1\end{array}$ & $\begin{array}{l}\text { Most widely used } \\
\text { Discriminates } \\
\text { remission from } \\
\text { active disease }\end{array}$ & $\begin{array}{l}\text { Not validated } \\
\text { Relies on subjective } \\
\text { Physician Global } \\
\text { assessment }\end{array}$ & 2 \\
\hline & $\begin{array}{l}\text { Pediatric } \\
\text { Ulcerative } \\
\text { Colitis } \\
\text { Activity } \\
\text { Index }{ }^{13}\end{array}$ & PUCAI & $\begin{array}{l}0-85 \\
\text { Remission: } \\
<10\end{array}$ & $\begin{array}{l}\text { Validated } \\
\text { Reliable and } \\
\text { responsive in } \\
\text { adults } \\
\text { Might permit less } \\
\text { frequent } \\
\text { endoscopic } \\
\text { assessment }\end{array}$ & $\begin{array}{l}\text { Has not been } \\
\text { widely adopted in } \\
\text { the adult population }\end{array}$ & 3 \\
\hline & $\begin{array}{l}\text { Truelove } \\
\text { and Witts' } \\
\text { Severity } \\
\text { Index }{ }^{14}\end{array}$ & TWC & & $\begin{array}{l}\text { Objective criteria } \\
\text { for acute severe } \\
\text { colitis. } \\
\text { Useful for } \\
\text { prognosis }\end{array}$ & $\begin{array}{l}\text { Not validated, } \\
\text { although widely } \\
\text { used }\end{array}$ & 4 \\
\hline
\end{tabular}




\begin{tabular}{|c|c|c|c|c|c|c|}
\hline \multirow[t]{2}{*}{ Endoscopic } & $\begin{array}{l}\text { Mayo Clinic } \\
\text { Index: } \\
\text { endoscopic } \\
\text { sub-score }^{11}\end{array}$ & & $\begin{array}{l}0-3 \\
\text { Remission: } \leq 1\end{array}$ & $\begin{array}{l}\text { Easy to use } \\
\text { Commonly used } \\
\text { in clinical trials } \\
\text { and clinical } \\
\text { practice }\end{array}$ & $\begin{array}{l}\text { Overlap of the } \\
\text { different levels } \\
\text { results in low inter- } \\
\text { observer } \\
\text { agreement } \\
\text { No validated } \\
\text { definition of } \\
\text { mucosal healing } \\
\text { Subjective terms } \\
\text { (minimal or slight } \\
\text { friability) reduce } \\
\text { concordance } \\
\text { Does not consider } \\
\text { disease extent }\end{array}$ & 5 \\
\hline & $\begin{array}{l}\text { Ulcerative } \\
\text { Colitis } \\
\text { Endoscopic } \\
\text { Index of } \\
\text { Severity } 8,9\end{array}$ & UCEIS & $\begin{array}{l}0-8 \\
\text { Remission: } \leq 1\end{array}$ & $\begin{array}{l}\text { Validated } \\
\text { Easy to use } \\
\text { High inter- } \\
\text { observer } \\
\text { reproducibility } \\
\text { Accounts for } 88 \% \\
\text { of variation } \\
\text { between } \\
\text { observers } \\
\text { Now used in } \\
\text { clinical trials }\end{array}$ & $\begin{array}{l}\text { No validated } \\
\text { definition of } \\
\text { mucosal healing or } \\
\text { response } \\
\text { Does not consider } \\
\text { disease extent } \\
\text { No thresholds for } \\
\text { mild, moderate and } \\
\text { severe disease }\end{array}$ & 6 \\
\hline \multirow[t]{4}{*}{ Histology } & $\begin{array}{l}\text { Riley Score } \\
38\end{array}$ & NA & $0-18$ & $\begin{array}{l}\text { Widely used, } \\
\text { simple, predictive } \\
\text { value in outcomes } \\
\text { in ulcerative colitis }\end{array}$ & $\begin{array}{l}\text { Partially validated, } \\
\text { includes items with } \\
\text { poor reproducibility }\end{array}$ & 7 \\
\hline & $\begin{array}{l}\text { Geboes } \\
\text { Score }^{39}\end{array}$ & NA & $\begin{array}{l}0.0-5.4 \\
\text { Remission: } \\
<3.1\end{array}$ & $\begin{array}{l}\text { Widely used, } \\
\text { predicts value in } \\
\text { outcomes in } \\
\text { ulcerative colitis }\end{array}$ & $\begin{array}{l}\text { Partially validated, } \\
\text { includes items with } \\
\text { poor reproducibility }\end{array}$ & 8 \\
\hline & $\begin{array}{l}\text { Nancy } \\
\text { Histological } \\
\text { Index }{ }^{6}\end{array}$ & NA & $\begin{array}{l}\text { 0-4 } \\
\text { Remission: } 0\end{array}$ & $\begin{array}{l}\text { Validated, } \\
\text { responsive, good } \\
\text { intra- and inter- } \\
\text { observer } \\
\text { agreement } \\
\text { Reliable, simple, } \\
\text { and easy to use }\end{array}$ & $\begin{array}{l}\text { Lacks data on } \\
\text { predictive value on } \\
\text { outcomes in } \\
\text { ulcerative colitis }\end{array}$ & 9 \\
\hline & $\begin{array}{l}\text { Robarts } \\
\text { histopatholo } \\
\text { gical index }{ }^{34}\end{array}$ & $\mathrm{RHI}$ & $\begin{array}{l}0-12 \\
\text { Remission: } \leq 6\end{array}$ & $\begin{array}{l}\text { Validated and } \\
\text { responsive } \\
\text { (compared with } \\
\text { endoscopic and } \\
\text { QOL indices) } \\
\end{array}$ & $\begin{array}{l}\text { Lack data on } \\
\text { predictive value on } \\
\text { outcomes in } \\
\text { ulcerative colitis }\end{array}$ & 10 \\
\hline \multirow[t]{3}{*}{ Radiology } & $\begin{array}{l}\text { Magnetic } \\
\text { resonance } \\
\text { colonograph } \\
\text { y simplified } \\
\text { index } 47\end{array}$ & MRC-S & $\begin{array}{l}0-4 \\
\text { Remission: } 0\end{array}$ & $\begin{array}{l}\text { Simple and } \\
\text { correlates well } \\
\text { with endoscopic } \\
\text { disease activity }\end{array}$ & $\begin{array}{l}\text { Not validated } \\
\text { Cost and availability } \\
\text { of MRI and } \\
\text { requirement for } \\
\text { bowel preparation }\end{array}$ & 11 \\
\hline & $\begin{array}{l}\text { Segmental } \\
\text { magnetic } \\
\text { resonance } \\
\text { score } 48\end{array}$ & MR-score-S & $\begin{array}{l}\text { 0-6 } \\
\text { Remission: } 0\end{array}$ & $\begin{array}{l}\text { Good } \\
\text { reproducibility and } \\
\text { inter-observer } \\
\text { agreement, } \\
\text { correlates well } \\
\text { with endoscopic } \\
\text { features } \\
\text { No need for bowel } \\
\text { preparation }\end{array}$ & $\begin{array}{l}\text { Not validated. } \\
\text { Cost and availability } \\
\text { of MRI }\end{array}$ & 12 \\
\hline & $\begin{array}{l}\text { Bowel } \\
\text { Ultrasound } \\
\text { Severity } \\
\text { Score } 49\end{array}$ & NA & $\begin{array}{l}\text { 0-3 } \\
\text { Remission: } 0\end{array}$ & $\begin{array}{l}\text { High concordance } \\
\text { between US score } \\
\text { and endoscopic } \\
\text { disease activity }\end{array}$ & $\begin{array}{l}\text { Not validated. } \\
\text { Dependent on } \\
\text { expert and } \\
\text { experienced }\end{array}$ & 13 \\
\hline
\end{tabular}




\begin{tabular}{|c|c|c|c|c|c|c|}
\hline & & & & $\begin{array}{l}\text { Bowel US score } \\
\text { predictive of } \\
\text { outcomes in } \\
\text { ulcerative colitis }\end{array}$ & sonographer & \\
\hline \multirow[t]{2}{*}{ Biomarkers } & $\begin{array}{l}\text { C-reactive } \\
\text { protein }\end{array}$ & CRP & $\begin{array}{l}0 \text { to }>200 \mathrm{mg} / \mathrm{l} \\
(1904 \mathrm{nmol} / \mathrm{l}) \\
\text { Remission: } \leq 3 \\
\text { to }<19 \mathrm{mg} / \mathrm{l}\end{array}$ & $\begin{array}{l}\text { Predictive of } \\
\text { outcomes in acute } \\
\text { severe colitis } \\
\text { (Oxford criteria*) } \\
\text { Widely available }\end{array}$ & $\begin{array}{l}\text { Less useful in mild } \\
\text { disease } \\
\text { Poor correlation } \\
\text { with endoscopic } \\
\text { disease activity }\end{array}$ & 14 \\
\hline & $\begin{array}{l}\text { Faecal } \\
\text { calprotectin }\end{array}$ & $\mathrm{FC}$ & $\begin{array}{l}0 \text { to }>1000 \mu \mathrm{g} / \mathrm{g} \\
\text { Remission: } \\
<50 \text { to }<250 \\
\mu \mathrm{g} / \mathrm{g}\end{array}$ & $\begin{array}{l}\text { Useful for } \\
\text { monitoring } \\
\text { disease activity in } \\
\text { ulcerative colitis } \\
\text { (using } \Delta \mathrm{FC} \text { ) }\end{array}$ & $\begin{array}{l}\text { Wide range of cut- } \\
\text { off values for } \\
\text { determining active } \\
\text { vs inactive disease } \\
\text { Lacks sensitivity } \\
\text { and specificity for } \\
\text { endoscopy disease } \\
\text { activity }\end{array}$ & NA \\
\hline \multirow[t]{3}{*}{$\begin{array}{l}\text { Quality of } \\
\text { Life }\end{array}$} & IBD-Control & IBD-Control & $\begin{array}{l}\text { Maximum of } \\
16 \text { for IBD- } \\
\text { Control-8 } \\
\text { ( } 16=\text { best } \\
\text { quality of life) }\end{array}$ & $\begin{array}{l}\text { Easy to use. } \\
\text { No licensing fee. } \\
\text { Captures disease } \\
\text { control from } \\
\text { patient's } \\
\text { perspective. }\end{array}$ & $\begin{array}{l}\text { Calculating total } \\
\text { score requires the } \\
\text { answers to be } \\
\text { translated. }\end{array}$ & 15 \\
\hline & $\begin{array}{l}\text { Short } \\
\text { Inflammatory } \\
\text { Bowel } \\
\text { Disease } \\
\text { Questionnair } \\
\mathrm{e}^{76}\end{array}$ & SIBDQ & $10-70$ & $\begin{array}{l}\text { Easy to use } \\
\text { Results correlate } \\
\text { to the longer 32- } \\
\text { item IBDQ } \\
\text { Widely accepted } \\
\text { Validated } \\
\text { Reproducible and } \\
\text { responsive }\end{array}$ & $\begin{array}{l}\text { Licensing fee } \\
\text { required for use }\end{array}$ & 16 \\
\hline & $\begin{array}{l}\text { Crohn's } \\
\text { Ulcerative } \\
\text { Colitis } \\
\text { Questionnair } \\
\text { e-8 } 77\end{array}$ & CUCQ-8 & $0-8$ & $\begin{array}{l}\text { Easy to use } \\
\text { Results correlate } \\
\text { with longer 32- } \\
\text { item questionnaire } \\
\text { Validated } \\
\text { No licensing fee }\end{array}$ & $\begin{array}{l}\text { Calculating total } \\
\text { score requires each } \\
\text { question to be } \\
\text { translated into a } \\
\text { subscore out of } 1 .\end{array}$ & 17 \\
\hline
\end{tabular}

1 For a full list of identified indices, please see Supplementary information S1 (table 1).

2 *Oxford criteria defined as more than eight stools per day or 3-8 stools per day and

3 plasma CRP concentration $>45 \mathrm{mg} / \mathrm{l}$. FC, faecal calprotectin; NA, not applicable;

4 QOL, quality of life; US, ultrasonography.

5

6 Table 2: Crohn's disease activity assessment indices in clinical practice

7

\begin{tabular}{|c|c|c|c|c|c|c|}
\hline Domain & Index Name & Abbreviation & $\begin{array}{l}\text { Range } \\
\text { (remission } \\
\text { threshold) }\end{array}$ & Strengths & Weaknesses & $\begin{array}{l}\text { Supp } \\
\text { I. } \\
\text { Table } \\
\text { Num } \\
\text { ber }\end{array}$ \\
\hline \multirow[t]{2}{*}{ Clinical } & $\begin{array}{l}\text { Crohn's } \\
\text { Disease } \\
\text { Activity } \\
\text { Index } 80\end{array}$ & CDAI & $\begin{array}{l}0-600 \\
\text { Remission: } \\
<150\end{array}$ & Widely used. & $\begin{array}{l}\text { Complex calculation } \\
\text { involving a 7-day } \\
\text { diary } \\
\text { High variability } \\
\text { Low contribution to } \\
\text { total score for } \\
\text { perianal disease }\end{array}$ & 18 \\
\hline & $\begin{array}{l}\text { Harvey- } \\
\text { Bradshaw } \\
\text { Index }{ }^{82}\end{array}$ & $\mathrm{HBI}$ & $\begin{array}{l}0-50 \\
\text { Remission: } \leq 4\end{array}$ & $\begin{array}{l}\text { Simpler, less } \\
\text { cumbersome } \\
\text { Does not require } \\
\text { a 7-day diary } \\
\text { Correlates well } \\
\text { with CDAl }\end{array}$ & $\begin{array}{l}\text { Low contribution to } \\
\text { total score for } \\
\text { perianal disease }\end{array}$ & 19 \\
\hline
\end{tabular}




\begin{tabular}{|c|c|c|c|c|c|c|}
\hline & $\begin{array}{l}\text { Perianal } \\
\text { Crohn's } \\
\text { Disease } \\
\text { Activity } \\
\text { Index } 84\end{array}$ & PDAI & $0-19$ & Easy to use & $\begin{array}{l}\text { Does not allow } \\
\text { documentation of } \\
\text { fistula severity }\end{array}$ & 20 \\
\hline \multirow[t]{3}{*}{ Endoscopic } & $\begin{array}{l}\text { Crohn's } \\
\text { Disease } \\
\text { Endoscopic } \\
\text { Index of } \\
\text { Severity }{ }^{87}\end{array}$ & CDEIS & $\begin{array}{l}0-44 \\
\text { Remission: }<3\end{array}$ & $\begin{array}{l}\text { Current gold- } \\
\text { standard } \\
\text { Reproducible } \\
\text { and validated } \\
\text { Extensively used } \\
\text { in clinical trials }\end{array}$ & $\begin{array}{l}\text { Complex } \\
\text { Cumbersome to use } \\
\text { in clinical practice } \\
\text { Needs experience } \\
\text { and training } \\
\text { No validated } \\
\text { definition of } \\
\text { mucosal healing } \\
\text { No correlation with } \\
\text { CDAl }\end{array}$ & 21 \\
\hline & $\begin{array}{l}\text { Simple } \\
\text { Endoscopic } \\
\text { Score for } \\
\text { Crohn's } \\
\text { disease }^{88}\end{array}$ & SES-CD & $0-56$ & $\begin{array}{l}\text { Simplified } \\
\text { version of the } \\
\text { CDEIS. } \\
\text { Validated } \\
\text { Performance } \\
\text { correlates well } \\
\text { with CDEIS }\end{array}$ & $\begin{array}{l}\text { Only slightly less } \\
\text { complex than } \\
\text { CDEIS } \\
\text { Validated against } \\
\text { CDEIS in only one } \\
\text { study } \\
\text { No validated } \\
\text { definition of } \\
\text { mucosal healing } \\
\text { No correlation with } \\
\text { CDAI } \\
\text { Less frequently } \\
\text { used in clinical trials }\end{array}$ & 22 \\
\hline & $\begin{array}{l}\text { Rutgeerts' } \\
\text { Post- } \\
\text { operative } \\
\text { Endoscopic } \\
\text { Index }{ }^{89,90} r\end{array}$ & NA & $\begin{array}{l}\text { i0 to i4 } \\
\text { Remission: }<i 2\end{array}$ & $\begin{array}{l}\text { Standard for } \\
\text { evaluating post- } \\
\text { operative } \\
\text { recurrence } \\
\text { Strong } \\
\text { prognostic } \\
\text { relevance } \\
\text { Widely used in } \\
\text { clinical practice } \\
\text { and trials }\end{array}$ & $\begin{array}{l}\text { Discriminative } \\
\text { ability unclear, } \\
\text { especially of the i2 } \\
\text { domain } \\
\text { Only for use after } \\
\text { ileocolic resection }\end{array}$ & 23 \\
\hline Histology & $\begin{array}{l}\text { Colonic and } \\
\text { lleal Global } \\
\text { Histologic } \\
\text { Disease } \\
\text { Activity } \\
\text { Score } \\
11,95 \\
\end{array}$ & $\begin{array}{l}\text { CGHAS } \\
\text { IGHAS }\end{array}$ & $0-16$ & $\begin{array}{l}\text { Takes into } \\
\text { account patchy } \\
\text { disease activity }\end{array}$ & $\begin{array}{l}\text { Not validated. } \\
\text { No data on } \\
\text { reproducibility. } \\
\text { Inherit issues with } \\
\text { histological scoring } \\
\text { in Crohn's disease }\end{array}$ & 24 \\
\hline \multirow[t]{3}{*}{ Radiology } & $\begin{array}{l}\text { Magnetic } \\
\text { Resonance } \\
\text { Index of } \\
\text { Activity }{ }^{99-101}\end{array}$ & MaRIA & $\begin{array}{l}\text { Segmental } \\
\text { mucosal } \\
\text { healing }<7 \\
\text { Segmental } \\
\text { ulcer healing } \\
<11\end{array}$ & $\begin{array}{l}\text { Validated. } \\
\text { Good intra- } \\
\text { observer and } \\
\text { inter-observer } \\
\text { concordance, } \\
\text { correlates well } \\
\text { with endoscopy } \\
\text { Responsive } \\
\text { index }\end{array}$ & $\begin{array}{l}\text { Might be best used } \\
\text { in clinical trials } \\
\text { rather than clinical } \\
\text { practice }\end{array}$ & 25 \\
\hline & $\begin{array}{l}\text { Van Assche } \\
\text { MRI-Based } \\
\text { Score for } \\
\text { Severity of } \\
\text { Perianal } \\
\text { Crohn's } \\
\text { Disease } 103\end{array}$ & NA & $0-24$ & $\begin{array}{l}\text { Validated } \\
\text { Good inter- } \\
\text { observer } \\
\text { concordance }\end{array}$ & $\begin{array}{l}\text { Utility in clinical } \\
\text { practice might be } \\
\text { limited due to } \\
\text { complexity }\end{array}$ & 26 \\
\hline & $\begin{array}{l}\text { Limberg } \\
\text { scoring } \\
\text { system for } \\
\text { bowel } \\
\text { ultrasonog } \\
\text { raphy } 108\end{array}$ & Limberg Score & $0-4$ & Widely used & Not validated & 27 \\
\hline
\end{tabular}




\begin{tabular}{|c|c|c|c|c|c|c|}
\hline \multirow[t]{2}{*}{ Biomarkers } & $\begin{array}{l}\text { C-reactive } \\
\text { protein }\end{array}$ & CRP & $\begin{array}{l}0 \text { to }>200 \mathrm{mg} / \mathrm{l} \\
\text { Remission: } \leq 5 \\
\text { to }<8 \mathrm{mg} / \mathrm{l}\end{array}$ & $\begin{array}{l}\text { Useful for } \\
\text { monitoring } \\
\text { disease activity } \\
\text { in Crohn's } \\
\text { disease } \\
\text { Predictive of } \\
\text { relapse whilst on } \\
\text { therapy and } \\
\text { following } \\
\text { withdrawal }\end{array}$ & $\begin{array}{l}\text { Modest correlation } \\
\text { with endoscopic } \\
\text { disease activity } \\
\text { (especially ileal } \\
\text { disease) }\end{array}$ & NA \\
\hline & $\begin{array}{l}\text { Faecal } \\
\text { calprotectin }\end{array}$ & $\mathrm{FC}$ & $\begin{array}{l}0 \text { to } \\
>1000 \mu \mathrm{g} / \mathrm{g} \\
\text { Remission: } \\
<50 \text { to }<250 \\
\mu \mathrm{g} / \mathrm{g}\end{array}$ & $\begin{array}{l}\text { Useful for } \\
\text { monitoring } \\
\text { disease activity } \\
\text { in Crohn's } \\
\text { disease (using } \\
\Delta \mathrm{FC} \text { ) }\end{array}$ & $\begin{array}{l}\text { Wide range of cut- } \\
\text { off values for } \\
\text { determining active } \\
\text { vs inactive disease. } \\
\text { Lacks sensitivity } \\
\text { and specificity for } \\
\text { endoscopy disease } \\
\text { activity }\end{array}$ & NA \\
\hline \multirow[t]{3}{*}{$\begin{array}{l}\text { Quality of } \\
\text { Life }\end{array}$} & $\begin{array}{l}\text { IBD-Control } \\
\text { (IBD- } \\
\text { Control-8 } \\
\text { also used) }\end{array}$ & $\begin{array}{l}\text { IBD-Control } \\
\text { IBD-Control-8 }\end{array}$ & $\begin{array}{l}\text { Maximum } \\
\text { score of } \\
\text { [Au:Can you } \\
\text { provide the } \\
\text { maximum } \\
\text { score?] for full } \\
\text { score } \\
\text { Maximum of } \\
16 \text { for IBD- } \\
\text { Control-8 } \\
\text { (16 = best } \\
\text { quality of life) }\end{array}$ & $\begin{array}{l}\text { Easy to use. } \\
\text { No licensing fee. } \\
\text { Captures } \\
\text { disease control } \\
\text { from patient's } \\
\text { perspective. }\end{array}$ & $\begin{array}{l}\text { Calculating total } \\
\text { score requires the } \\
\text { answers to be } \\
\text { translated. }\end{array}$ & 15 \\
\hline & $\begin{array}{l}\text { Short } \\
\text { Inflammatory } \\
\text { Bowel } \\
\text { Disease } \\
\text { Questionnair } \\
\mathrm{e}^{76}\end{array}$ & SIBDQ & $\begin{array}{l}10-70 \\
(10=\text { best } \\
\text { QOL })\end{array}$ & $\begin{array}{l}\text { Easy to calculate } \\
\text { total score. } \\
\text { Results correlate } \\
\text { to the longer 32- } \\
\text { item IBDQ } \\
\text { Widely accepted } \\
\text { Validated } \\
\text { Reproducible } \\
\text { and responsive }\end{array}$ & $\begin{array}{l}\text { Licensing fee } \\
\text { required for use }\end{array}$ & 16 \\
\hline & $\begin{array}{l}\text { Crohn's } \\
\text { Ulcerative } \\
\text { Colitis } \\
\text { Questionnair } \\
\text { e-8 }\end{array}$ & CUCQ-8 & $\begin{array}{l}0-8 \\
(0=\text { best } Q O L)\end{array}$ & $\begin{array}{l}\text { Easy to use } \\
\text { Results correlate } \\
\text { with longer 32- } \\
\text { item } \\
\text { questionnaire } \\
\text { Validated } \\
\text { No licensing fee }\end{array}$ & $\begin{array}{l}\text { Calculating total } \\
\text { score requires each } \\
\text { question to be } \\
\text { translated into a } \\
\text { subscore out of } 1 .\end{array}$ & 17 \\
\hline
\end{tabular}

2 For a full list of identified indices, please see Supplementary information S1 (table 2). FC,

3 faecal calprotectin; NA, not applicable; QOL, quality of life.

4

5

6

7 


\section{Online only info}

\section{Author biographies:}

Simon Travis is the Professor of Clinical Gastroenterology at the University of Oxford, UK, and a former President of the European Crohn's and Colitis Organisation (2012-2014). He is a Fellow of Linacre College and Consultant Gastroenterologist at Oxford University Hospitals NHS Trust, with research interests in predictive factors, clinical trial outcomes, novel therapy, endoscopic assessment and patient-reported outcomes for inflammatory bowel disease.

Robert Bryant is a Consultant Gastroenterologist at the Royal Adelaide Hospital, Australia, and a PhD candidate at the University of Adelaide. He undertook a Clinical Fellowship in Inflammatory Bowel Diseases within the Oxford University Hospitals NHS Trust (20132014) and thereafter a Master of Science by Research at the University of Oxford (20142015). He is actively involved in research involving diet, body composition, disease activity assessment, optimizing outcomes, and predictive factors in inflammatory bowel disease.

Alissa Walsh is a Consultant Gastroenterologist at St Vincent's Hospital Sydney, Australia, currently undertaking a DPhil at the University of Oxford, UK. After completing her formal gastroenterology training in Australia, she undertook a Clinical Fellowship in Inflammatory Bowel Diseases within the Oxford University Hospitals NHS Trust (2007-2008) and thereafter a National Health Medical Research Council fellowship in Australia (2009-2011). She is actively involved in research involving inflammatory bowel disease activity indices, prevention of opportunistic infections in immunocompromised patients and the role of faecal transplantation in ulcerative colitis. Dr Walsh is a founder and director of Crohn's Colitis Cure and an active member of the Australia New Zealand IBD Consortium.

\section{Toc blurb}

Objective assessment of disease activity in IBD is crucial for successfully guiding therapy. Here, the authors comprehensively evaluate disease activity indices for their use in clinical practice and clinical trials, as well as assessing relevant biomarkers and measures of quality of life.

\section{Subject terms}

Health sciences / Gastroenterology / Gastrointestinal diseases / Inflammatory bowel disease [URI /692/4020/1503/257]

Health sciences / Signs and symptoms / Digestive signs and symptoms [URI /692/1807/1808]

Health sciences / Health care / Quality of life

[URI /692/700/784]

Health sciences / Health care / Medical imaging

[URI /692/700/1421] 